\title{
New faunistic records of the genus Erioptera MeIgen (Limoniidae, Diptera, Insecta) from Europe
}

\author{
Levente-Péter Kolcsár, Ádám Soos, Edina TöröK, Wolfram Graf, László RÁKosy \& Lujza KereszTES
}

\begin{abstract}
Summary: Here we report a number of species for the first time from various European countries. These are Erioptera (Erioptera) divisa (WALker, 1848) and E. (E.) lutea lutea (MeIgen, 1804) from Greece; E. (E.) flavata (Westhoff, 1882) and E. (E.) griseipennis (Meigen, 1838) from Bosnia and Herzegovina; E. (E.) fusculenta (Edwards, 1938) from Austria, Montenegro, and Serbia; $E$. (E.) longicauda (Loew, 1871) from Hungary; E. (E.) minor (DE MeIJERE, 1920) from Romania, and E. (Mesocyphona) bivittata (LoEw, 1873) from Serbia. Some rare Romanian Erioptera species, as E. (E.) limbata (LoEw, 1873), E. (E.) sordida (ZETTERSTEDT, 1838), E. (E.) verralli (EDWARDS, 1921) and E. (Mesocyphona) fossarum (LoEw, 1873) are also discussed.
\end{abstract}

Key words: new faunistic records, short-palped crane flies, Greece, Bosnia and Herzegovina, Romania

\section{Introduction}

The short-palped crane fly genus Erioptera Meigen, contains 286 species worldwide and 29 species are reliably known from the WestPalaearctic area (Oosterbroek 2017), and belong to two subgenera. The Erioptera subgenus contains 25 species and four species belong to the subgenus Mesocyphona Osten SAcken. Some members of the genus are uncommon and others are abundant species of different aquatic or semi-aquatic habitats (SALMELA 2001, Ujvárosi 2005, Podeniene 2009). The known larvae are detritivorous, living in various substrates like mud, sand, and wet leaf litter among streams and rivers banks, and lake shores (PoDENIENE 2002, 2009). Larva of Erioptera (Mesocyphona) bivittata (LoEw, 1873) can tolerate high salinity and are found around saline-influenced lakes and coastal marshes (Stubbs 2003, Podeniene 2009).

Despite the fact that they are abundant in their habitats, Erioptera species biology, ecology and distribution are poorly known. Here we report a number of species for the first time from various European countries and discussing theirs habitat preference.

\section{Material and methods}

Specimens were collected between 1999 and 2017 using sweep nets and the material was stored in $70 \%$ ethanol and deposited in Diptera Collection of the Faculty of Biology and Geology, Babeş-Bolyai
University, Cluj-Napoca, Romania (DCBBU). The morphological characteristics of the male terminalia was examined by Kolcsár L.-P. KereszTes L. and Soos Á., after being macerated in $10 \% \mathrm{KOH}$. Layer photos were taken using an Olympus CX23 LED microscope equipped with a Canon 750D camera. All collection data are listed in Table 1 and also are available on the TransDiptera Online Database (KolCSÁr et al. 2017).

\section{Results}

During our investigation a number of 971 Erioptera individuals belonging to 12 different species were identified. We list in the text only the locations which represents the first record for a species from a country. For a complete list of data see Table 1.

New faunistic records:

Order: DIPTERA

Family: LIMONIIDAE

Subfamily: CHIONEINAE

Erioptera (Erioptera) divisa (WALKER, 1848) (Fig. 1.).

Material examined: Greece, Lithachon, Olympos Mts., 2003 m, 40.0724 $\mathrm{N} 22.4208^{\circ} \mathrm{E}, 09.07 .2012$, 1 male, leg. RÁKosy L.

Remarks: It is a widely distributed species in the Western-Palearctic, but mostly absent from Mediterranean Areas (Oosterbroek 2017). The specimen was collected from a high mountainous area (about $2000 \mathrm{~m}$ ) in Greece. The species probably is 
a glacial relict in the South-Balkan region and it is known to also have a restricted montane distribution in the Carpathians. Larvae are found in mud at the edge of brooks, rivers, and lakes (PoDENIENE 2002, 2009) in Lithuania . The lead author's experience is that the species is found at muddy shores of mountain streams.

Erioptera (Erioptera) flavata (WESTHOFF, 1882) (Fig. 2.).

Material examined: Bosnia and Herzegovina, Pedise, $965 \mathrm{~m}, 43.9636^{\circ} \mathrm{N} 18.7430^{\circ} \mathrm{E}, 12.07 .2008$, 2 males, leg. BÁLINT M.

Remarks: It is a relatively common species in boggy, marshy habitats (BOARDMAN 2007, UJvárosI et al. 2011, SALMELA 2012). In the Romanian Carpathians it prefers the lower sections of mountain brooks, where the stream has muddy backwaters, and often swarms above the vegetation during windless afternoons, often very close $(40-50 \mathrm{~cm})$ to swarms of E. lutea. Detailed description of swarming and mating behavior of Erioptera flava (as gemina) published by Savolainen \& Syrjämäki (1971).

Erioptera (Erioptera) fusculenta (EDWARDS, 1938) (Fig. 3.).

Material examined: Austria, Vienna, Lansgrund Oben, $155 \mathrm{~m}, 48.1905^{\circ} \mathrm{N} 16.5193^{\circ} \mathrm{E}, 12.06 .2012,1$ male, 29.08.2012, 2 males, leg. W. GRAF. Montenegro, Buljarica, $20 \mathrm{~m}, 42.1969^{\circ} \mathrm{N} 18.9654^{\circ} \mathrm{E}, 26.06 .2017,1$ male, leg. Kolcsár L.-P., TöRÖK E. Serbia, Banatska Palanka, Kanal DTD, $67 \mathrm{~m}, 44.8583^{\circ} \mathrm{N} 21.3053^{\circ} \mathrm{E}$, 30.04.2017, 7 males, 2 females, leg. Kolcsár L.-P., TöRÖK E.

Remarks: It is a common species, occurring in a range of different habitats (STARÝ and Delmastro 2001, Ujvárosi 2005, BOARDMAN 2007, Ujvárosi et al. 2011, KolCSÁr et al. 2013), but prefer wet. All specimens listed here were collected at the sides of canals and backwaters with a thick mud layer.

Erioptera (Erioptera) griseipennis (MEIGEN, 1838) (Fig. 4.).

Material examined: Bosnia and Herzegovina, Jezero, Boracko Lake, $400 \mathrm{~m}, 43.5554^{\circ} \mathrm{N} 18.0281^{\circ}$ E, 05.05.2017, 6 males, 2 females, leg. Kolcsár L.P., ТӧвӧK E.

Remarks: It is a Western-Palearctic species (Oosterbroek 2017), and as other Erioptera species, prefers wet habitats (ASHE and CONNOR 2005, BOARDMAN 2007). It was collected in a boggy area around a small mountain stream in Bosnia and Herzegovina, and was frequently found together with E. flava in the Romanian Carpathians.

Erioptera (Erioptera) longicauda (LoEw, 1871) (Fig. 5-6.).

Material examined: Hungary, Szilvásvárad, Bükk
Mts., Szalajka Valley, $461 \mathrm{~m}, 48.0844^{\circ} \mathrm{N} 20.4062^{\circ}$ E, 16.08.2013, 1 male, leg. KolCSÁR L.-P., TÖRÖK E. Remarks: This is a rare species reported only from Bulgaria, Czech Republic, France, Great Britain, Greece, Poland, and Romania (Oosterbroek 2017), and the ecology of this cranefly is poorly understood. The Hungarian specimen was collected around a muddy pond next to a calcareous sandy stream.

Erioptera (Erioptera) lutea lutea (MEIGEN, 1804) (Fig. 7.).

Material examined: Greece, Lithachon, Olympos Mts., $2003 \mathrm{~m}, 40.0724^{\circ} \mathrm{N} 22.4208^{\circ} \mathrm{E}, 09.07 .2012,5$ males, leg. RÁkosy L.

Remarks: It is a very common and abundant species in various wetland habitats, but primary it prefers the riparian zone of ditches, small brooks and rivers, and is almost absent from mountainous cold springs in Romania and the Balkans. The species often swarms above the vegetation during windless afternoons and swarms have been observed up to 70 flies. Beautiful demoiselle (Calopteryx virgo) was observed preying upon E. lutea lutea and E. flavata around small brooks in the După Luncă marsh near Voșlăbeni, Romania.

Erioptera (Erioptera) minor (DE MEIJERE, 1920) (Fig. 5, 8.).

Material examined: Romania, Voșlobeni, Giurgeu Basin, Senetea, marshy area, $762 \mathrm{~m}, 46.6296^{\circ} \mathrm{N}$ 25.5910 ${ }^{\circ}$ E, 06.07.2011, 1 male, leg. KolCsár L.-P.

Remarks: A rare species, this fly was previously reported from Czech Republic, Germany, Lithuania, Netherlands, and Slovakia (Oosterbroek 2017) and is found in lowland swamps, marshes, and marshy meadows (Starý 1983, PodĖNAs 2008). The Romanian specimen was collected around a small stream in După Luncă marsh.

Erioptera (Mesocyphona) bivittata (LoEw, 1873) (Fig. 9.)

Material examined: Serbia, Banatska Palanka, Kanal DTD, $67 \mathrm{~m}, 44.8583^{\circ} \mathrm{N} 21.3053^{\circ} \mathrm{E}$, 30.04.2017, 7 males, 2 females, leg. Kolcsár L.-P., TöRÖK E.

Remarks: A widely distributed species that can tolerate high salinity habitats (STUBBS 2003, Podeniene 2009, Oosterbroek 2017). The Serbian specimens were collected around a freshwater canal with a thick mud layer. In Romania the species is known from both hilly and lowland areas, and is associated with streams and rivers.

\section{Additional records}

Erioptera (Erioptera) limbata (LoEw, 1873) (Fig. 5.).

Material examined: see Table 1.

Remarks: The species is widely distributed in the 


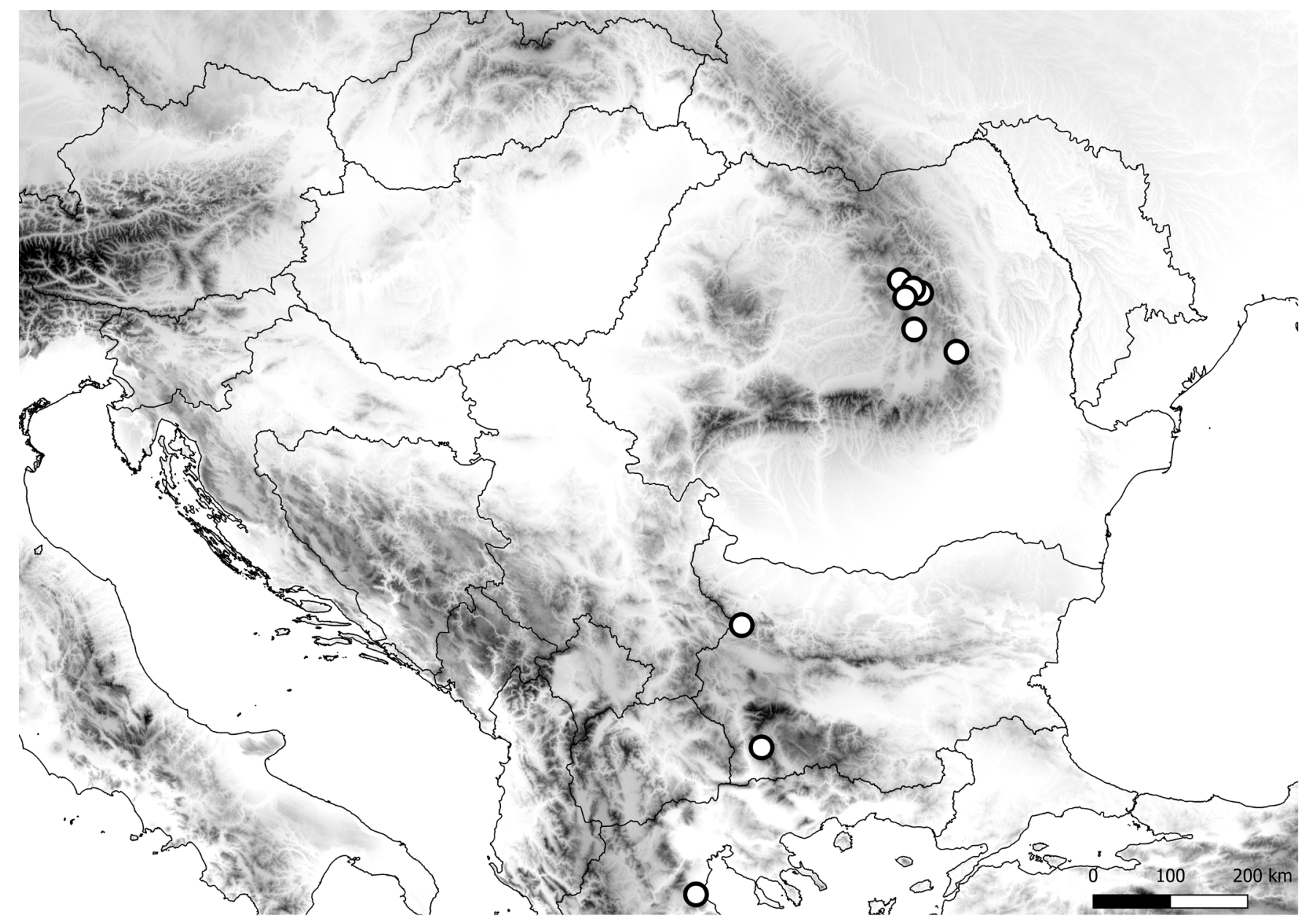

Fig. 1. Location of collection sites of Erioptera (Erioptera) divisa (WALKER, 1848).

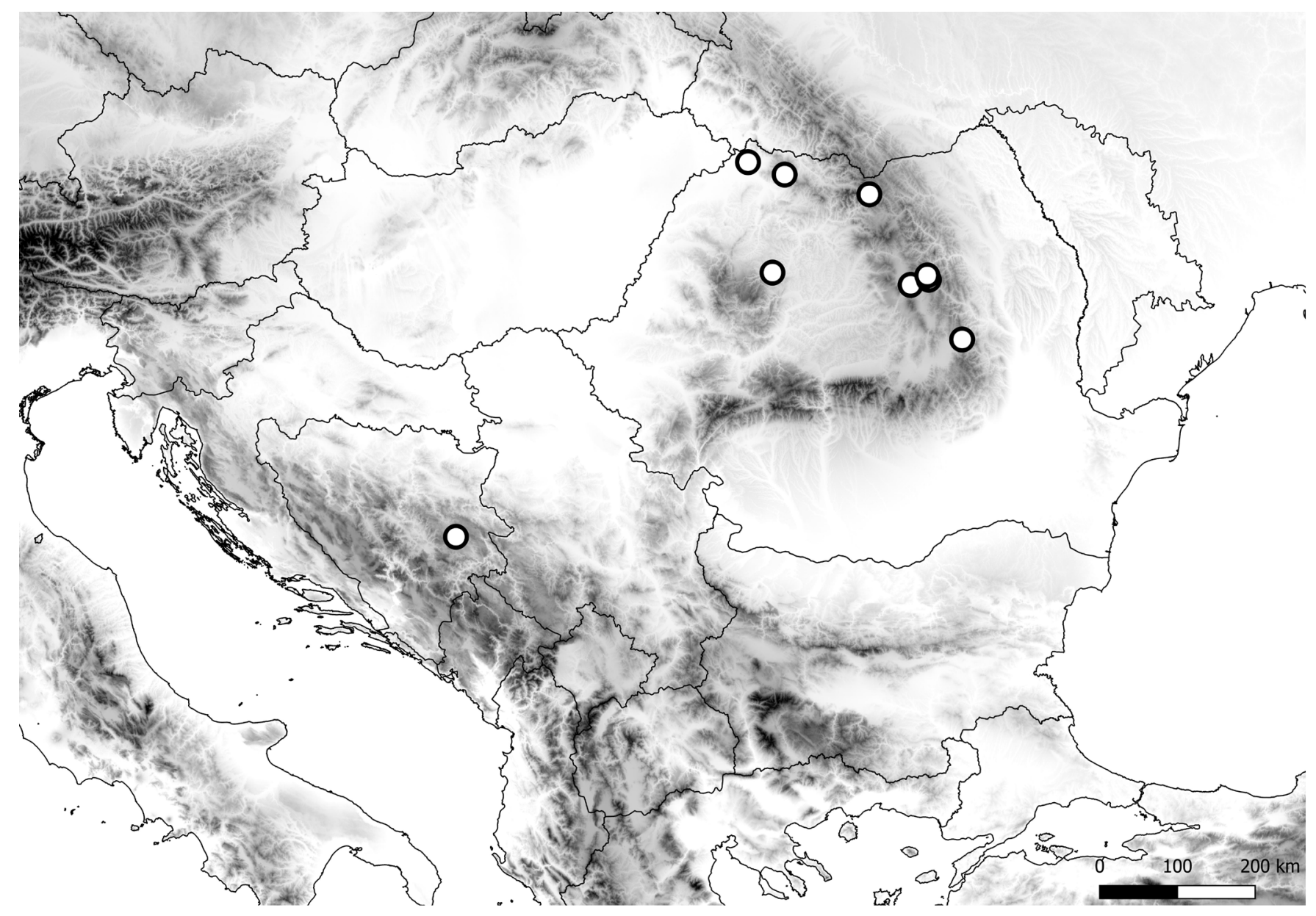

Fig. 2. Location of collection sites of Erioptera (Erioptera) flavata (WESTHOFF, 1882). 


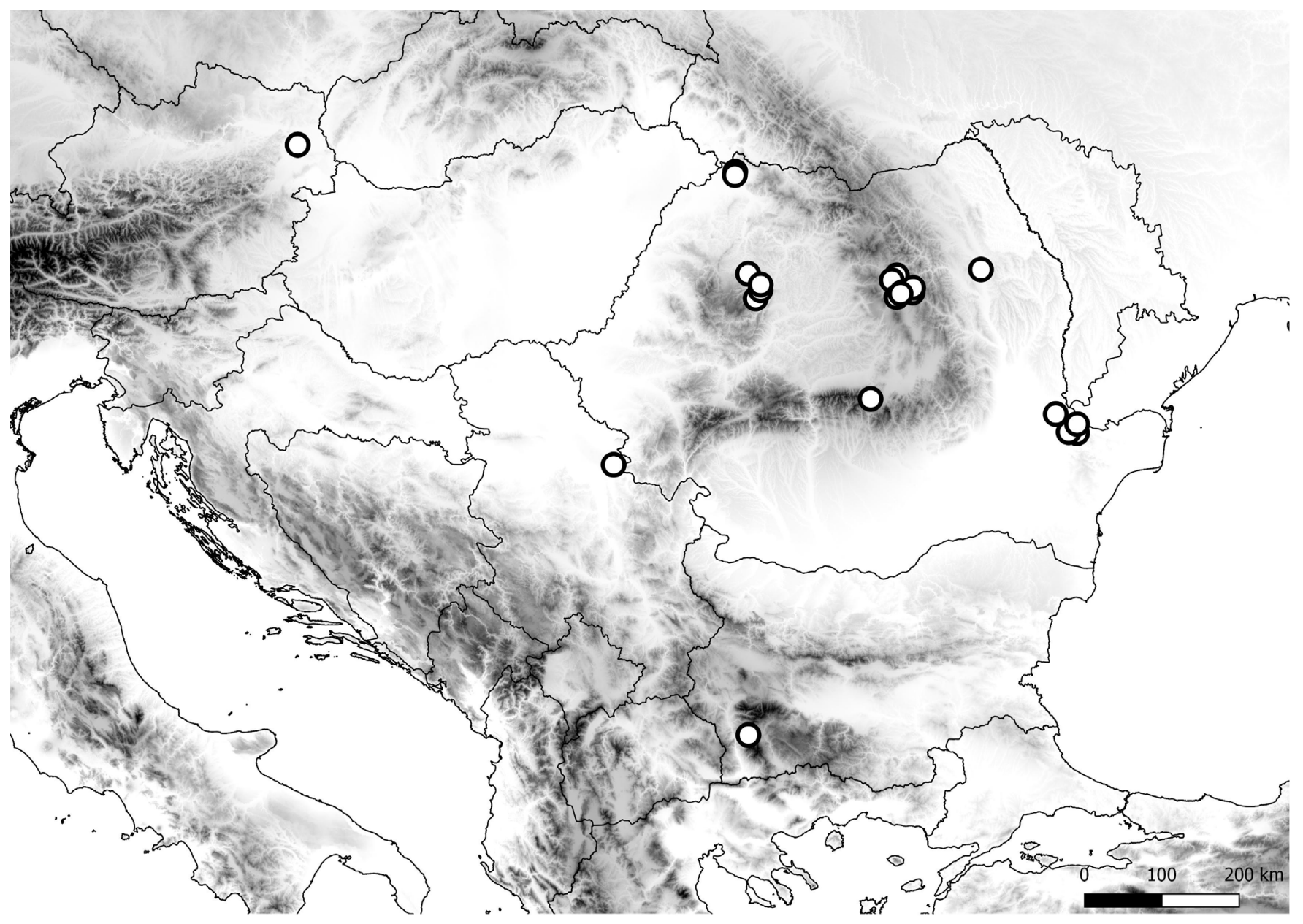

Fig. 3. Location of collection sites of Erioptera (Erioptera) fusculenta (EDWARDS, 1938).

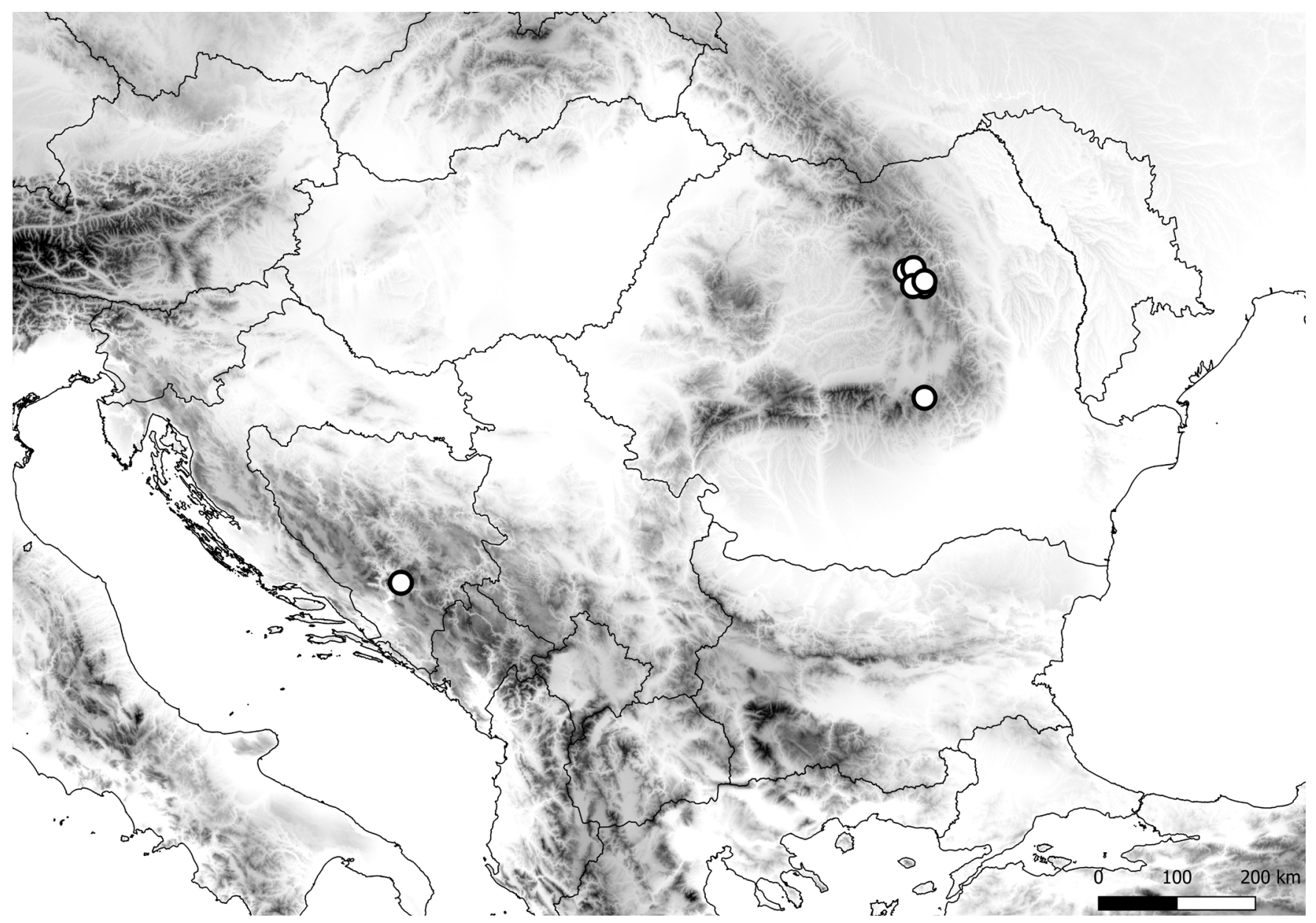

Fig. 4. Location of collection sites of Erioptera (Erioptera) griseipennis (MEIGEN, 1838). 


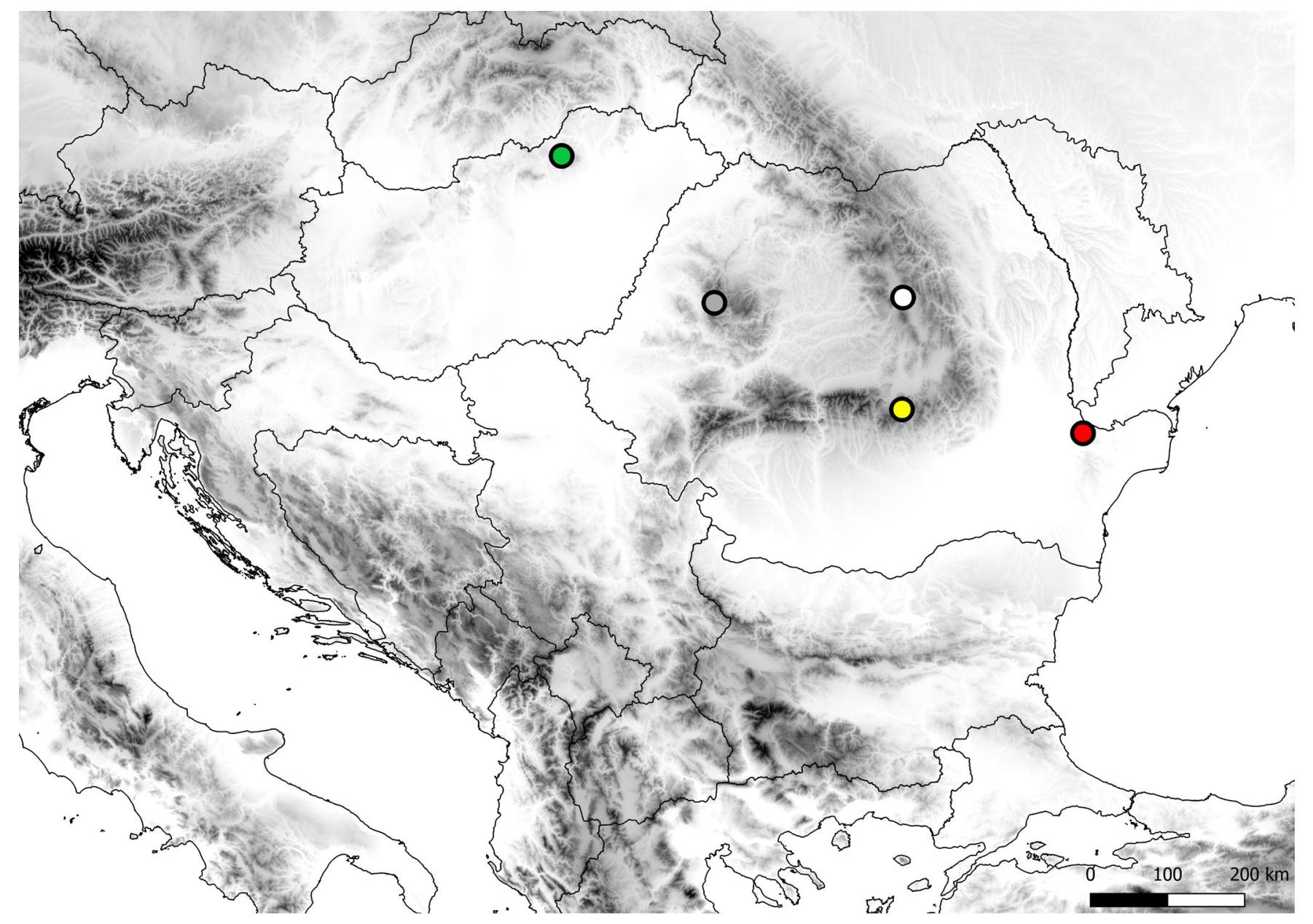

Fig. 5. Location of collection sites of Erioptera (Erioptera) longicauda (LoEw, 1871) (green); E. (E.) minor (DE MEIJERE, 1920) (white); E. (E.) limbata (LoEw, 1873) (red); E. (E.) sordida (ZETTERSTEDT, 1838) (gray) and E. (E.) verralli (EDWARDS, 1921) (yellow).
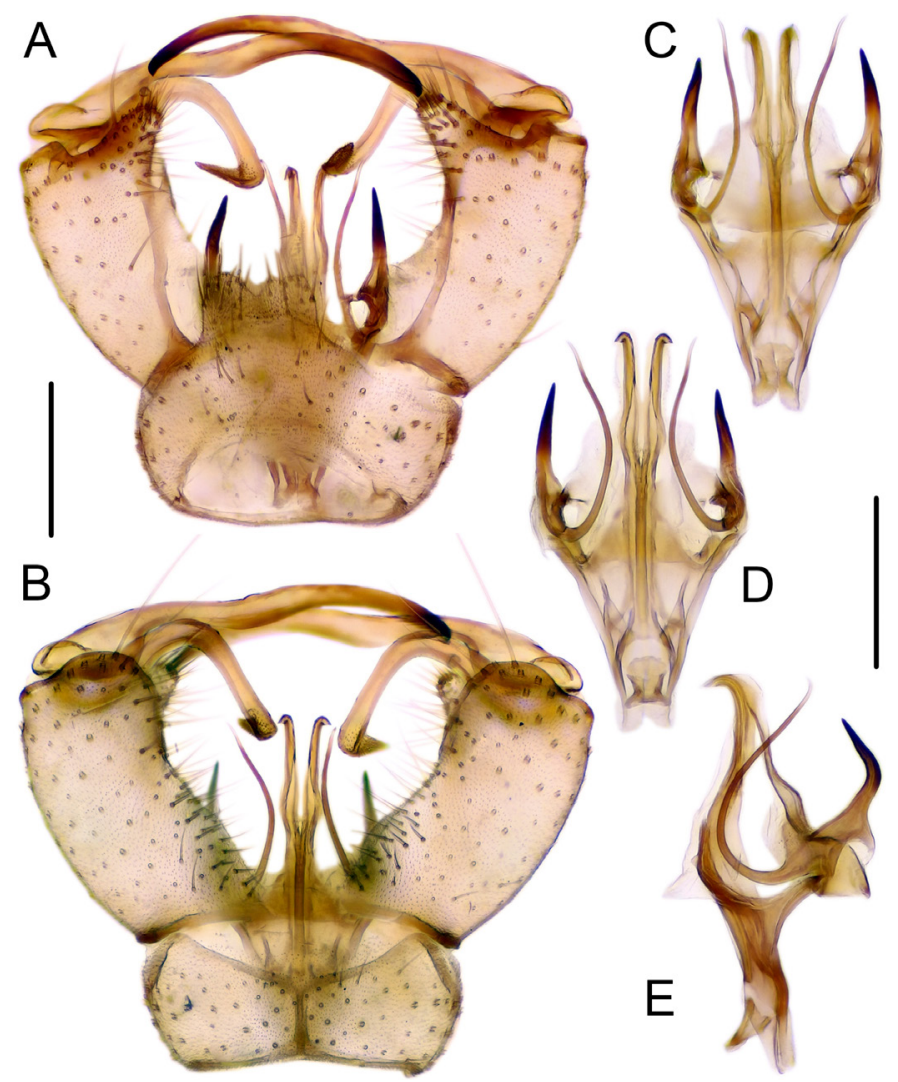

Fig. 6. Erioptera (Erioptera) longicauda LoEw, 1871: A - male hypopygium dorsal view; B - male hypopygium ventral view; $\mathrm{C}$ - aedeagus complex dorsal view; D - aedeagus complex ventral view; E - aedeagus complex lateral view. Scale bars: 0.2 mm 


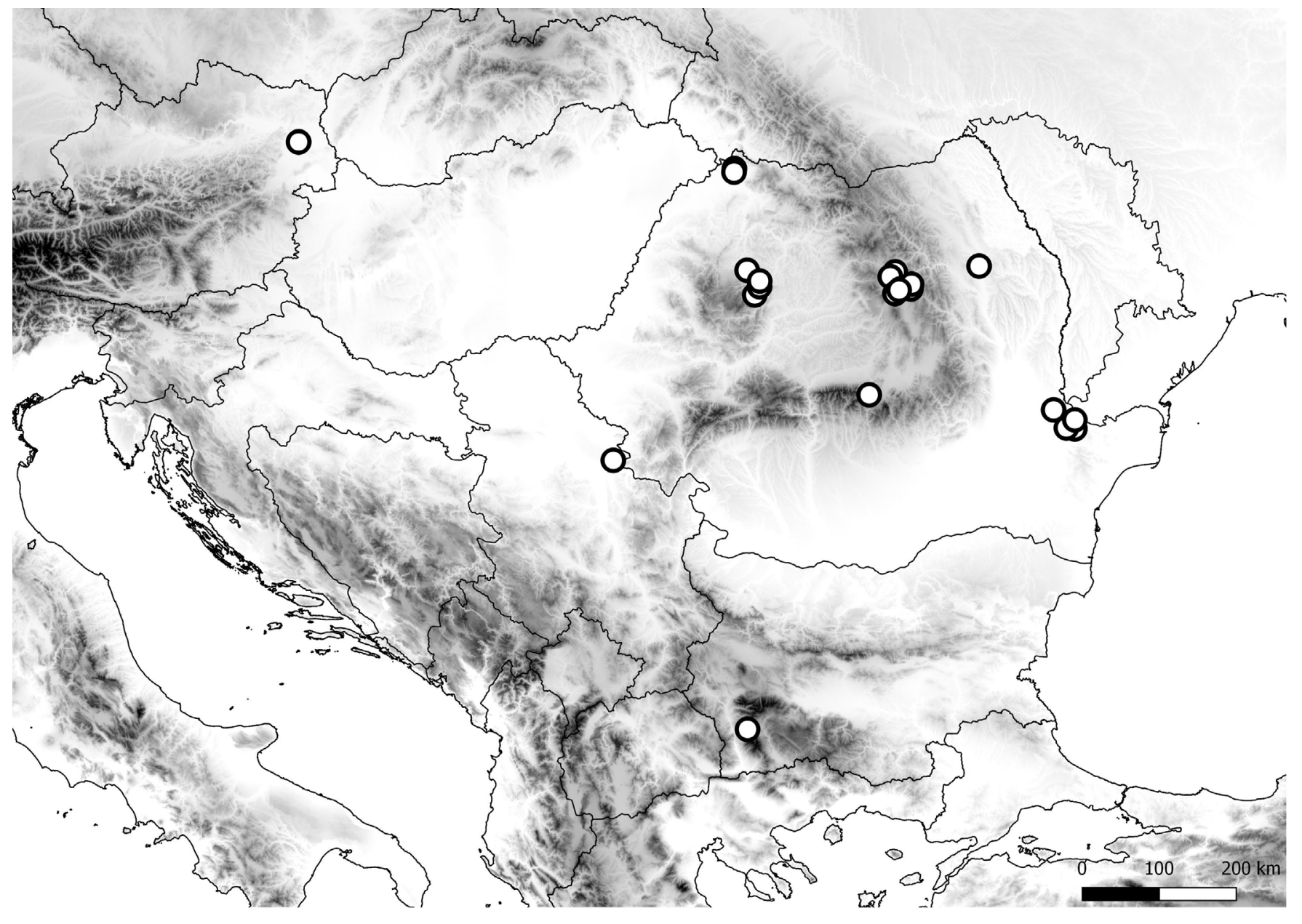

Fig. 7. Location of collection sites of Erioptera (Erioptera) lutea lutea (MEIGEN, 1804).
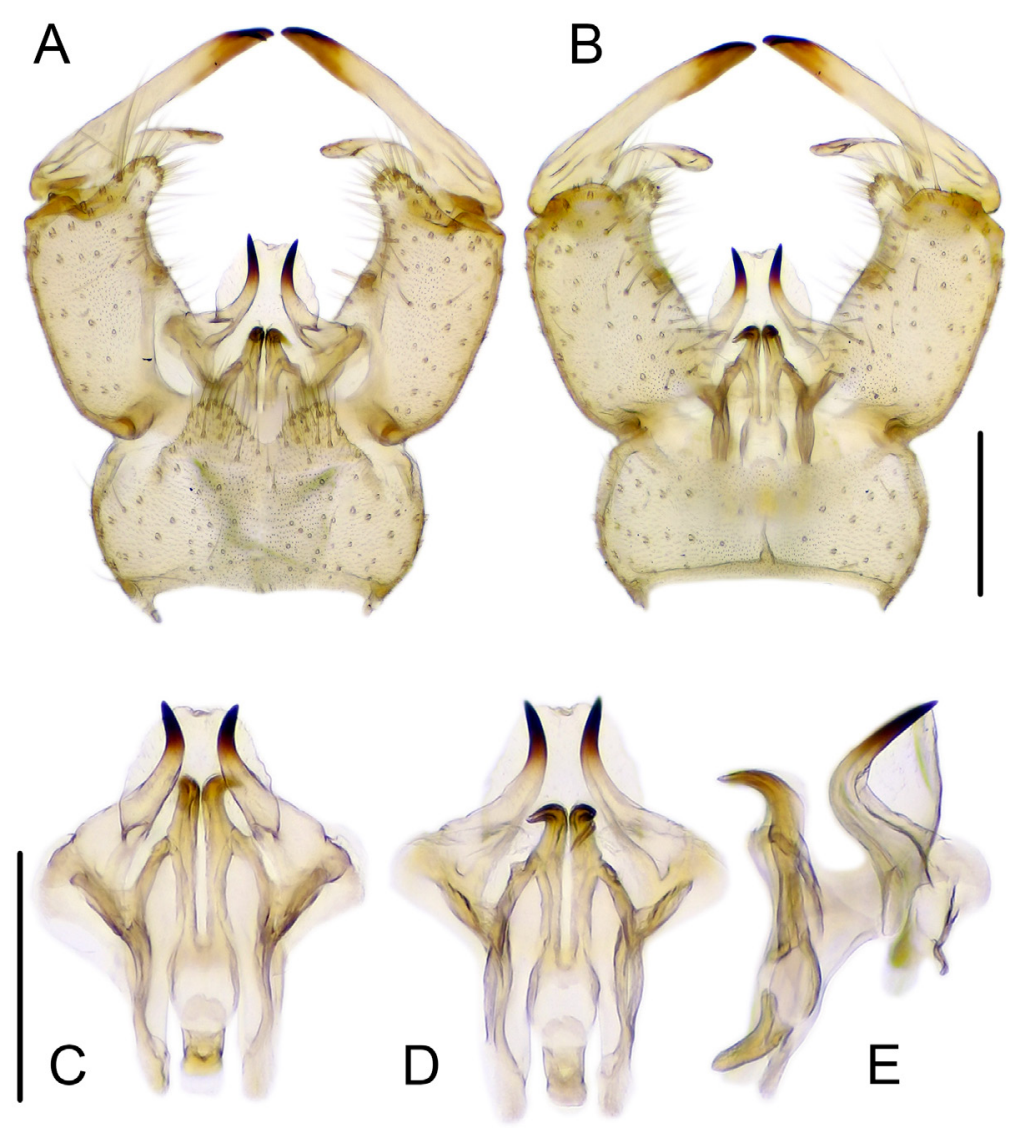

Fig. 8. Erioptera (Erioptera) minor DE MeIJERE, 1920: A - male hypopygium dorsal view; B - male hypopygium ventral view; $\mathrm{C}$ - aedeagus complex dorsal view; D - aedeagus complex ventral view; E - aedeagus complex lateral view. Scale bars: $0.2 \mathrm{~mm}$ 


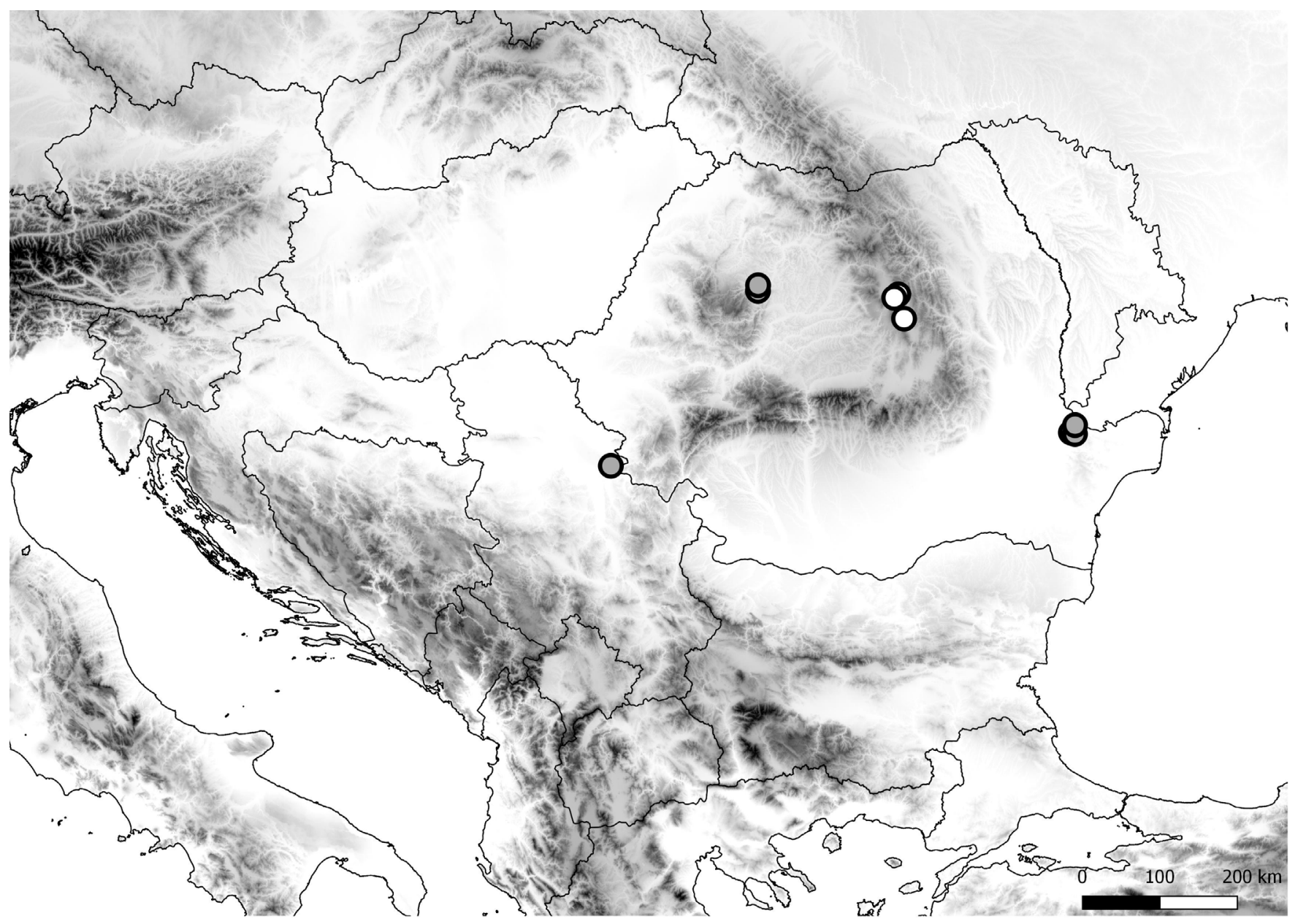

Fig. 9. Location of collection sites of Erioptera (Mesocyphona) bivittata (LoEw, 1873) (gray) and Erioptera (Mesocyphona) fossarum (LoEw, 1873) (white).

European Atlantic and Continental climatic zone, including mountainous areas (OOSTERBROEK 2017). The species is known to prefer the sandy riparian zone of rivers (Godfrey 1999, PoDENIENE 2002). Romanian specimens were collected around small brooks (which periodically dry out). It is probable that this species more common than records suggest from lowland rivers in Romania, which are poorly investigated habitats.

\section{Erioptera (Erioptera) sordida (ZETTERSTEDT,} 1838) (Fig. 5, 10.).

Material examined: see Table 1.

Remarks: It is a wide distributed species, but never abundant in its habitats. The species is mostly found in mesotrophic and meso-eutrophic swamps, fens and mire in Finland and Latvia (SAlmela 2001, 2008, Salmela and ILmonen 2005, SAlmela and VartiJa 2007). In Romania the species has been rarely collected, having previously been reported among swampy streams in the Eastern-Carpathians and from the Retezat Mts. (Astanei 1979, ERHAN-Dinca and Ceianu 1986, Ujvárosi and Póti 2006, Ujvárosi et al. 2011). We collected the species within a swampy area near a stream in the Apuseni Mts. The species has an early summer (May-June) phenology in Romania.
Erioptera (Erioptera) verralli (EDWARDS, 1921) (Fig. 5, 11.).

Material examined: see Table 1.

Remarks: The species was previously reported from wooded streams (GODFREY 1999, BOARDMAN 2007) in Great Britain. The habitat preference of the species remains sketchy, the only one specimen collected by us was found around a small mountain stream in spruce (Picea abies) dominated forest.

\section{Erioptera (Mesocyphona) fossarum (LoEw,} 1873) (Fig. 9.)

Material examined: see Table 1.

Remarks: This is a rare and local species, previously reported only from: Czech Republic, France, Hungary, Lithuania, Poland, Romania, Slovakia, Ukraine and East European Russia (OOSTERBroEK 2017). In Romania the species was collected from rocky and sandy banked sediments by a streamside in the Eastern-Carpathians.

\section{Aknowledgements}

The authors thank Miklós Bálint, Peter Neu, Áron Péter, Cintia Horváth, Réka Kiss and András Varró for collecting specimens. We thank Pete Boardman for his comments on the text. 


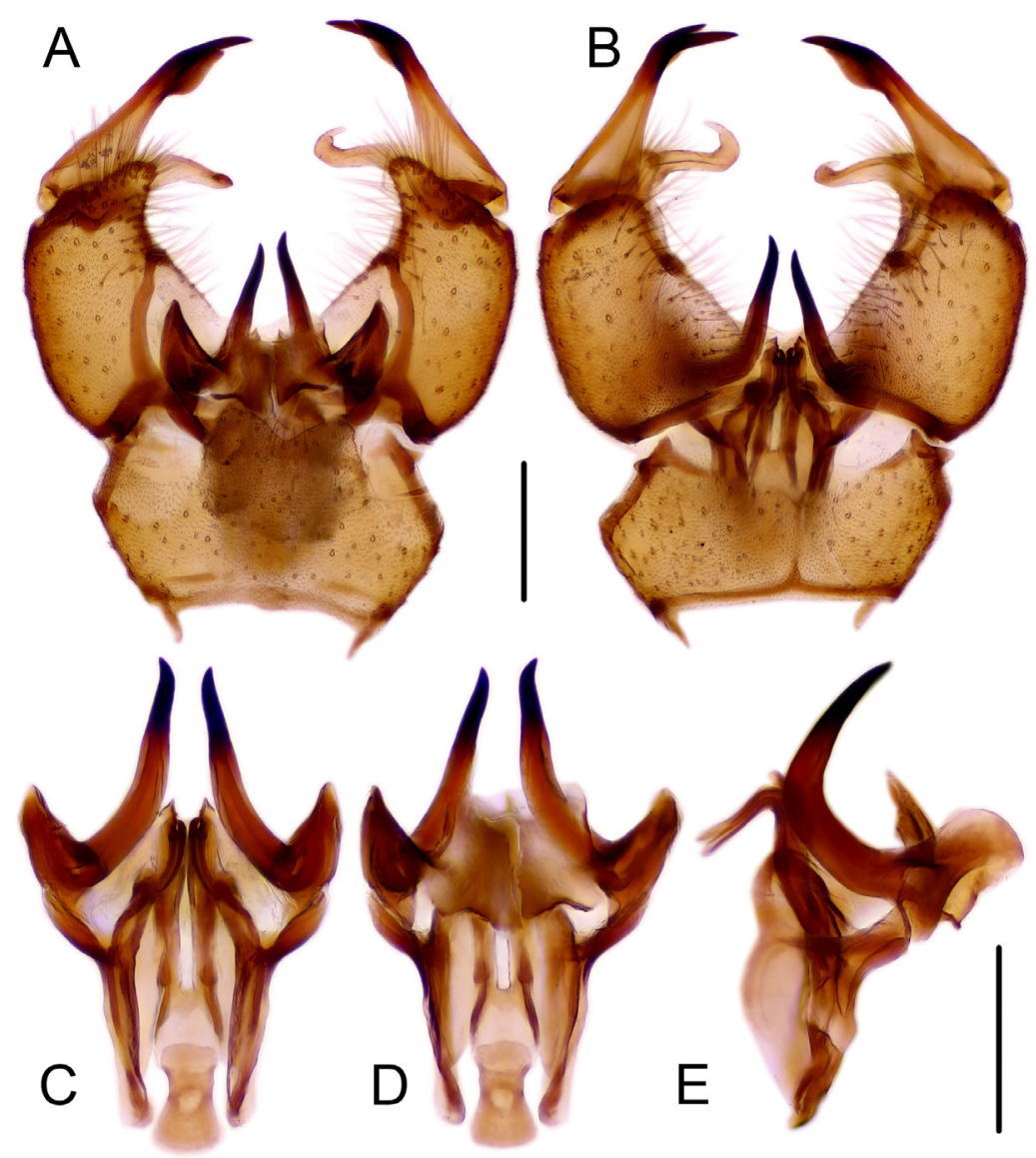

Fig. 10. Erioptera (Erioptera) sordida ZETTERSTEDT, 1838: A - male hypopygium dorsal view; B - male hypopygium ventral view; $\mathrm{C}$ - aedeagus complex dorsal view; D - aedeagus complex ventral view; E - aedeagus complex lateral view. Scale bars: $0.2 \mathrm{~mm}$

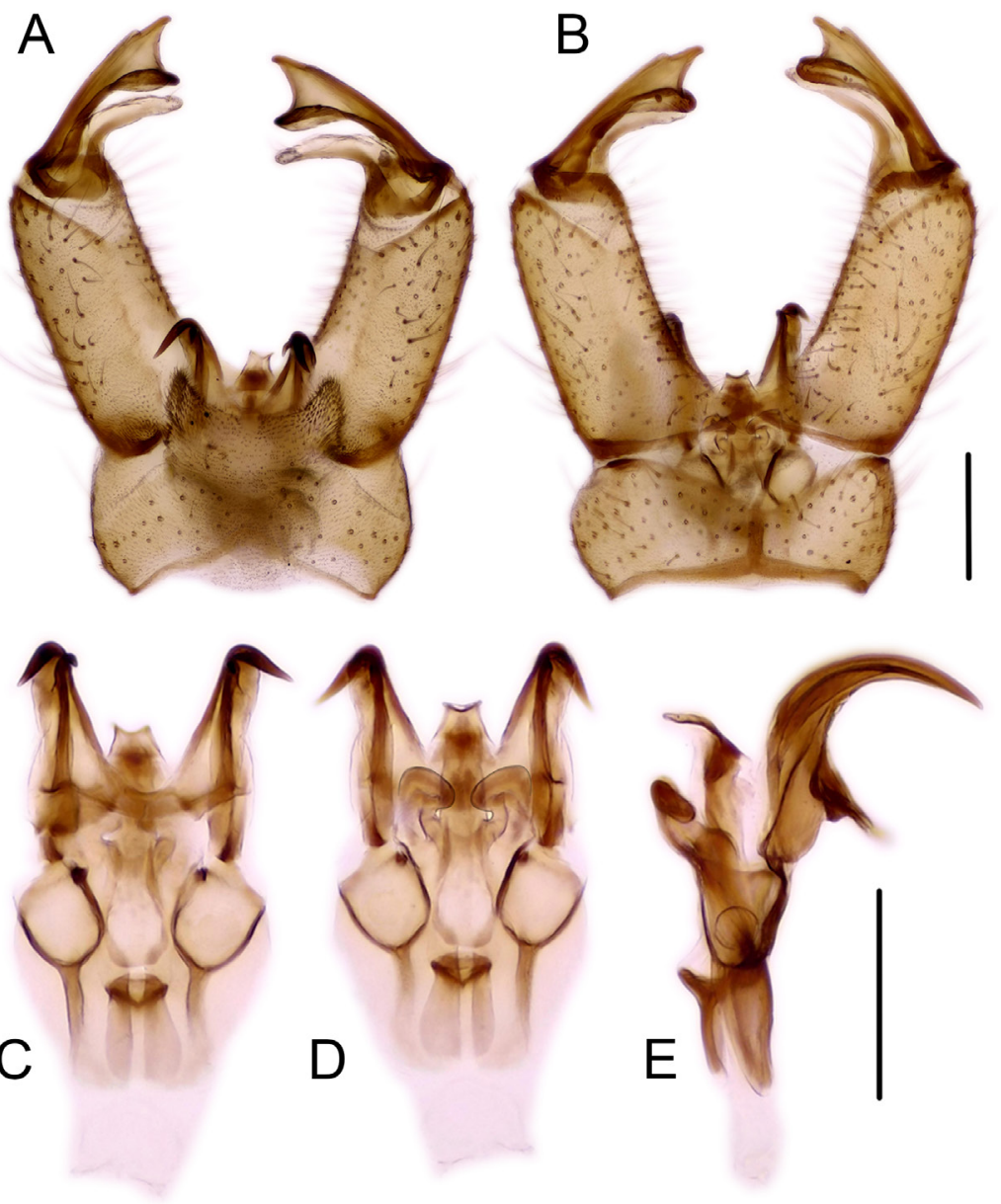

Fig. 11. Erioptera (Erioptera) verralli EDWARDS, 1921: A - male hypopygium dorsal view; B - male hypopygium ventral view; $\mathrm{C}$ - aedeagus complex dorsal view; D - aedeagus complex ventral view; E-aedeagus complex lateral view. Scale bars: $0.2 \mathrm{~mm}$ 


\section{References}

Ashe P. and O'Connor J. P. (2005) Erioptera (Erioptera) griseipennis MEIGEN and Hoplolabis (Parilisia) vicina (TonNOIR) (Diptera: Limoniidae), two craneflies new to Ireland. Entomologist's Gazette 56: 271-272.

Astanei V. (1979) Specii noi de Limoniidae (Diptera) in fauna Romaniei. Studii și comunicări, Muzeul de Ştiintele Naturii Bacău: 43-44.

BoARDMAN P. (2007) A provisional account and atlas of the craneflies of Shropshire. Privately published, Oswestry, UK, $96 \mathrm{pp}$.

DraKe C. M. (2011) The Diptera of a wet woodland in Devon. Dipterists Digest (2nd series) 18: 9-26.

Erhan-Dinca E. and Ceianu I. (1986) Contribuții la cunoașterea faunei de Limoniiidae (Diptera) din nordul Carpaților Orientali ai Romaniei. Lucrarile celei de a III-a Conferinte de Entomologia, Iasi 1983 1: 85-92.

GodFrey A. (1999) A review of Diptera from exposed riverine sediments based on literature records. Dipterists Digest 6: 63-82.

KolcsÁr L.-P., TöröK E. and Keresztes L. (2013) Craneflies (Diptera: Tipulidae) and phantom craneflies (Diptera: Ptychopteridae) fauna around a metropolis (Cluj-Napoca, Romania). Acta Scietiarum Transylvanice 21: 66-78.

KolcsÁr L.-P., Veres R. and Keresztes L. (2017) TransDiptera Online Database. http://transdiptera.ro. accessed on: 20.11.2017. https://doi. org/10.18426/ OBM.5sskmlll3ip0

Oosterbroek P. (2017) Catalogue of the Craneflies of the World (Diptera, Tipuloidea: Pediciidae, Limoniidae, Cylindrotomidae, Tipulidae), http://ccw.naturalis.nl/, accessed on 20.11.2017.

PoDÉNAS S. (2008) First records of crane Flies (Diptera: Limoniidae, Tipulidae) for Lithuania in 2007. Acta Zoologica Lituanica 18(3): 207-210.

PoDENIENE V. (2002) Records on new and little-known larvae of the family Limoniidae (Diptera, Nematocera) from Lithuania. Acta Zoologica Lituanica 12: 294-308.

Podeniene V. (2009) Lithuanian Chioneinae (Limoniidae, Diptera): Larval habitat preferences and problems of identification, with description of last instar larvae of
Molophilus (Molophilus) crassipygus DE MeIJERE, 1918, M. (M.) griseus (MeIGeN, 1804), M. (M.) ochraceus (MeIgen, 1818), M. (M.) propinquus (EGGER, 1863). Lauterbornia 68: 135-145.

SAlmela J. (2001) Adult craneflies (Diptera: Nematocera) around springs in southern Finland. Entomologica Fennica 12: $139-152$

Salmela J. (2008) Semiaquatic fly (Diptera, Nematocera) fauna of fens, springs, headwater streams and alpine wetlands in the northern boreal ecoregion, Finland. W-album 6: 1-63.

SALMELAJ.(2012). Biogeographic patterns ofFinnish craneflies (Diptera, Tipuloidea). Psyche: A Journal of Entomology 2012: 1-20 doi: http://dx.doi.org/10.1155/2012/913710

SAlmela J. and Ilmonen J. (2005) Cranefly (Diptera: Tipuloidea) fauna of a boreal mire system in relation to mire trophic status: implications for conservation and bioassessment. Journal of Insect Conservation 9: 85-94.

Salmela J. and VARTIJA N.-A. (2007) New records of nematoceran flies (Diptera) from Latvia. Latvijas Entomologs 44: 11-14.

STARÝ J. (1983) New taxa of Limoniidae from Czechoslovakia (Diptera). Annotationes Zoologicae et Botanicae, Bratislava 154: 1-22.

Starý J. and Delmastro G. B. (2001) New records of Trichoceridae, Limoniidae and Ptychopteridae from Italy (Insecta, Diptera). Bollettino del Museo Regionale di Scienze Naturali Torino 18: 447-458.

Stubbs A. E. (2003) Tipulidae and Allies - Craneflies. Managing Priority Habitats for Invertebrates 17: 1-158

UjvÁrosi L. (2005) Limoniidae and Pediciidae (Insecta: Diptera) assemblages along mountainous streams: additions to assess the biodiversity in wet habitats in Carpathians, Romania. Acta Biologica Debrecina Oecologica Hungarica 13: 233-248.

Ujvárosi L., PóTI T. and Kolcsár L.-P. (2011) Lószúnyogszerü diptérák (Diptera, Tipuloidea) élöhelypreferenciája és szezonális diverzitása a Vaslábi rétlápban és annak környékén (Keleti Kárpátok). In: MARKó B. and SÁRKÁNYKIss E. (eds.): A Gyergyói-medence: egy mozaikos táj természeti értékei. Presa Universitara Clujeana/ Cluj University Press: 101-118.
Levente-Péter KoLCSÁR

Hungarian Department of Biology and

Ecology, Centre of Systems Biology,

Biodiversity and Bioresources,

Babeș-Bolyai University, Clinicilor 5-7,

Cluj-Napoca, Romania

E-mail: kolcsar.peter@gmail.com
Ádám Soos

Hungarian Department of Biology and Ecology, Centre of Systems Biology, Biodiversity and Bioresources,

Babeș-Bolyai University, Clinicilor 5-7, Cluj-Napoca, Romania

E-mail:soos.adam10@gmail.com
Edina TöRÖK

Hungarian Department of Biology and Ecology, Centre of Systems Biology, Biodiversity and Bioresources,

Babeș-Bolyai University, Clinicilor 5-7, Cluj-Napoca, Romania

Romanian Academy Institute of Biology, Splaiul Independenței 296, 060031

București, Romania

E-mail: edinatorok7@gmail.com

Lujza KereszTES

Hungarian Department of Biology and Ecology, Centre of Systems Biology, Biodiversity and Bioresources,

Babeș-Bolyai University, Clinicilor 5-7, Cluj-Napoca, Romania

E-mail: keresztes2012@gmail.com 


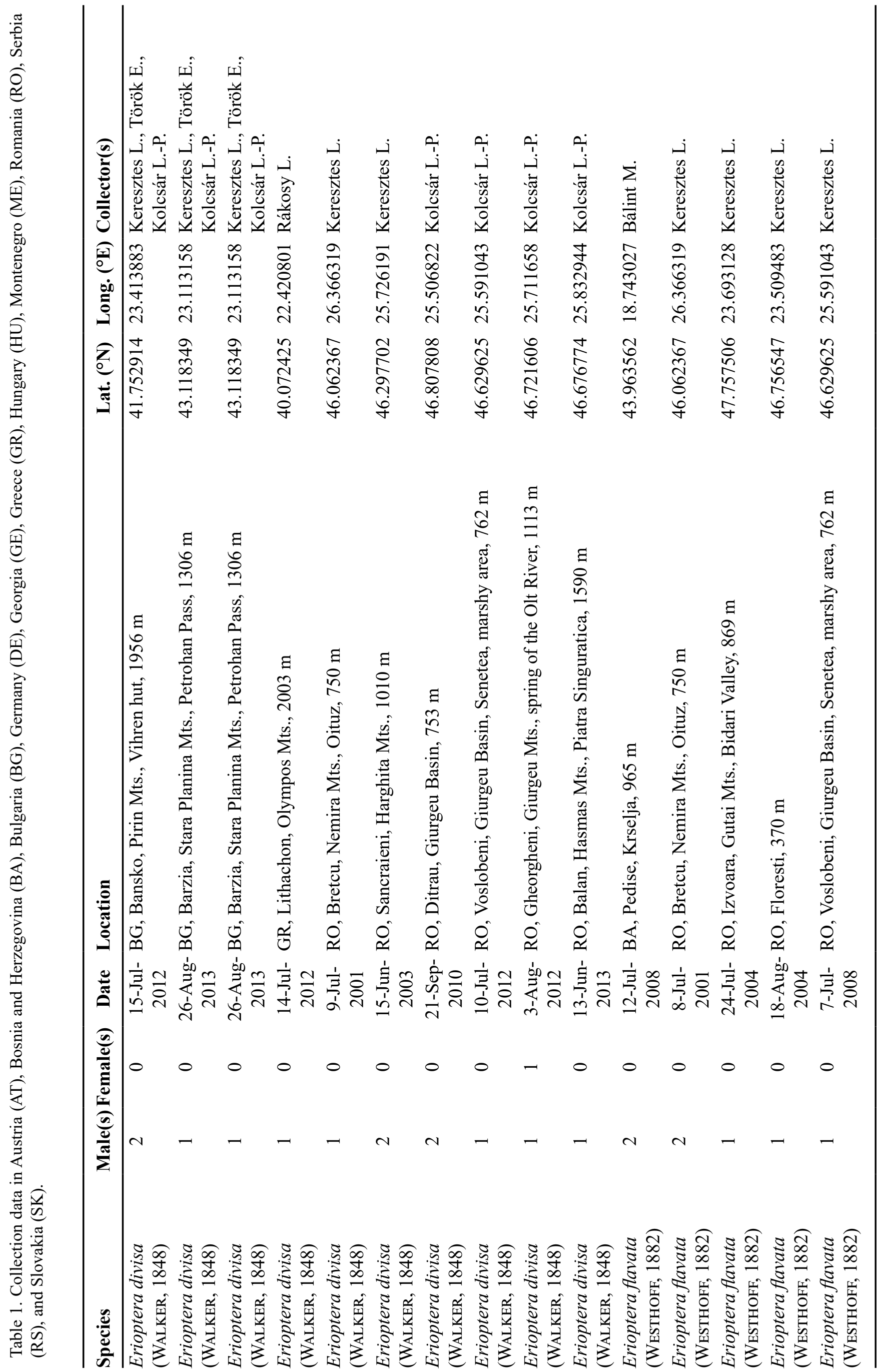




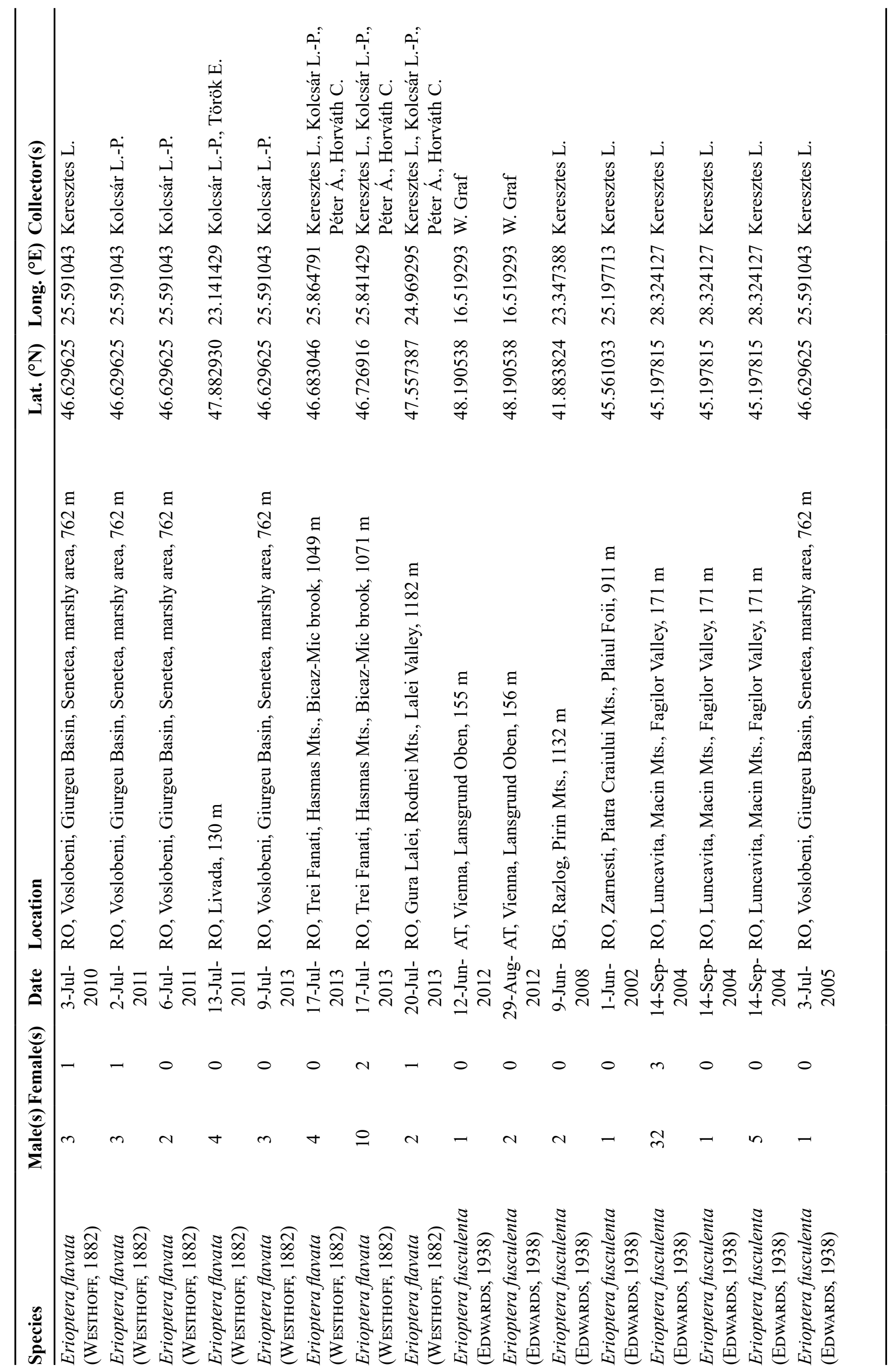




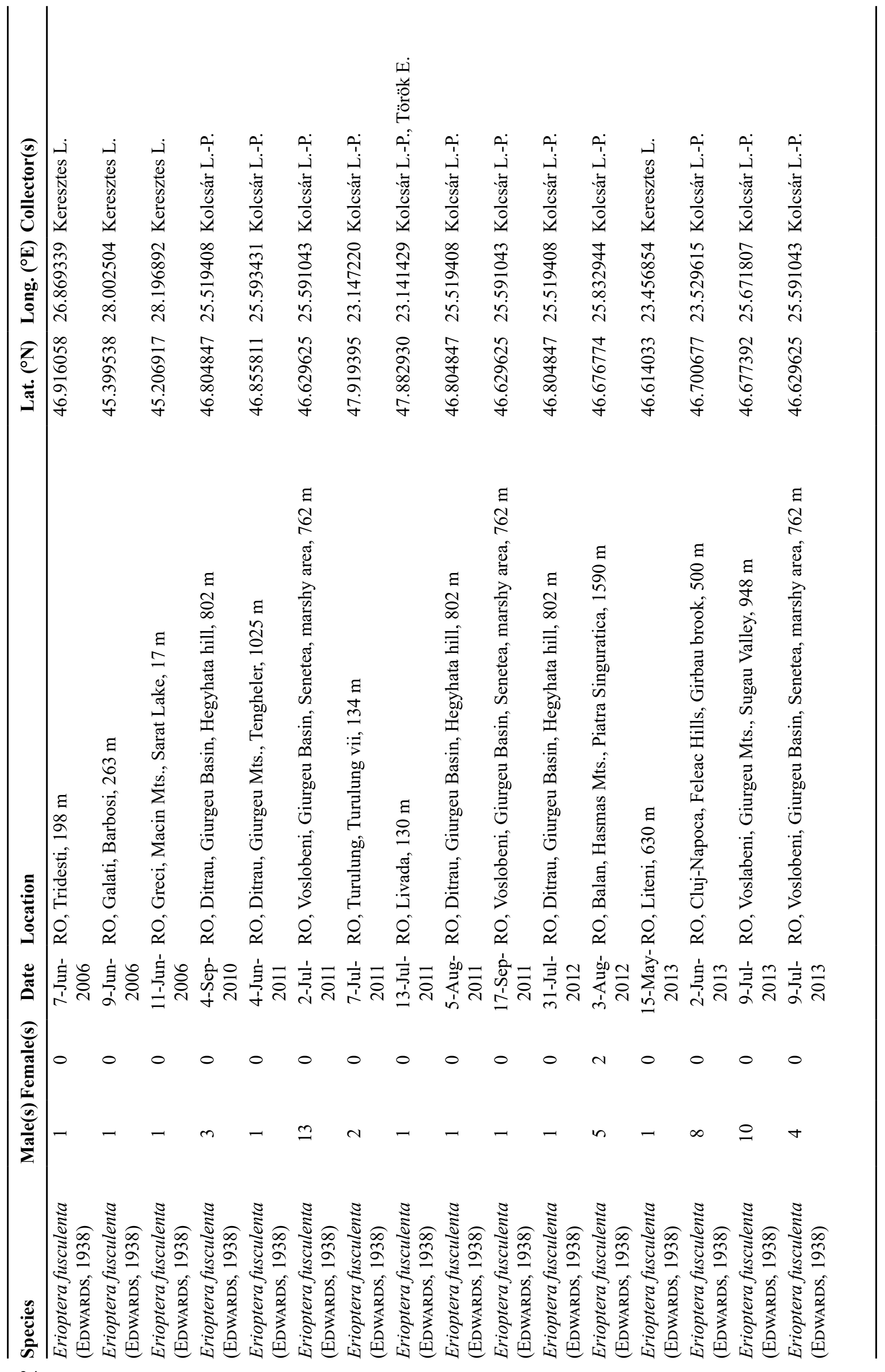




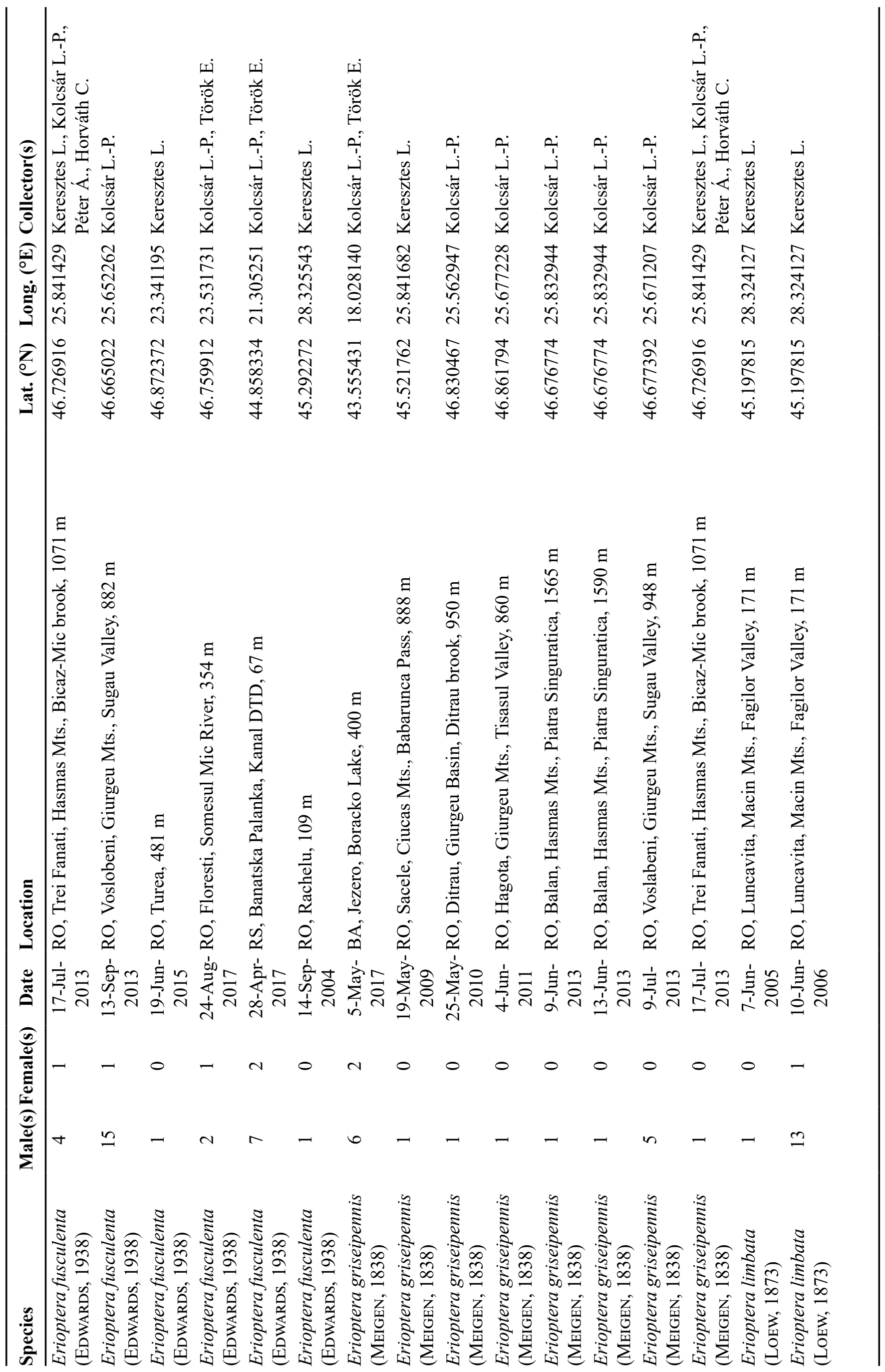




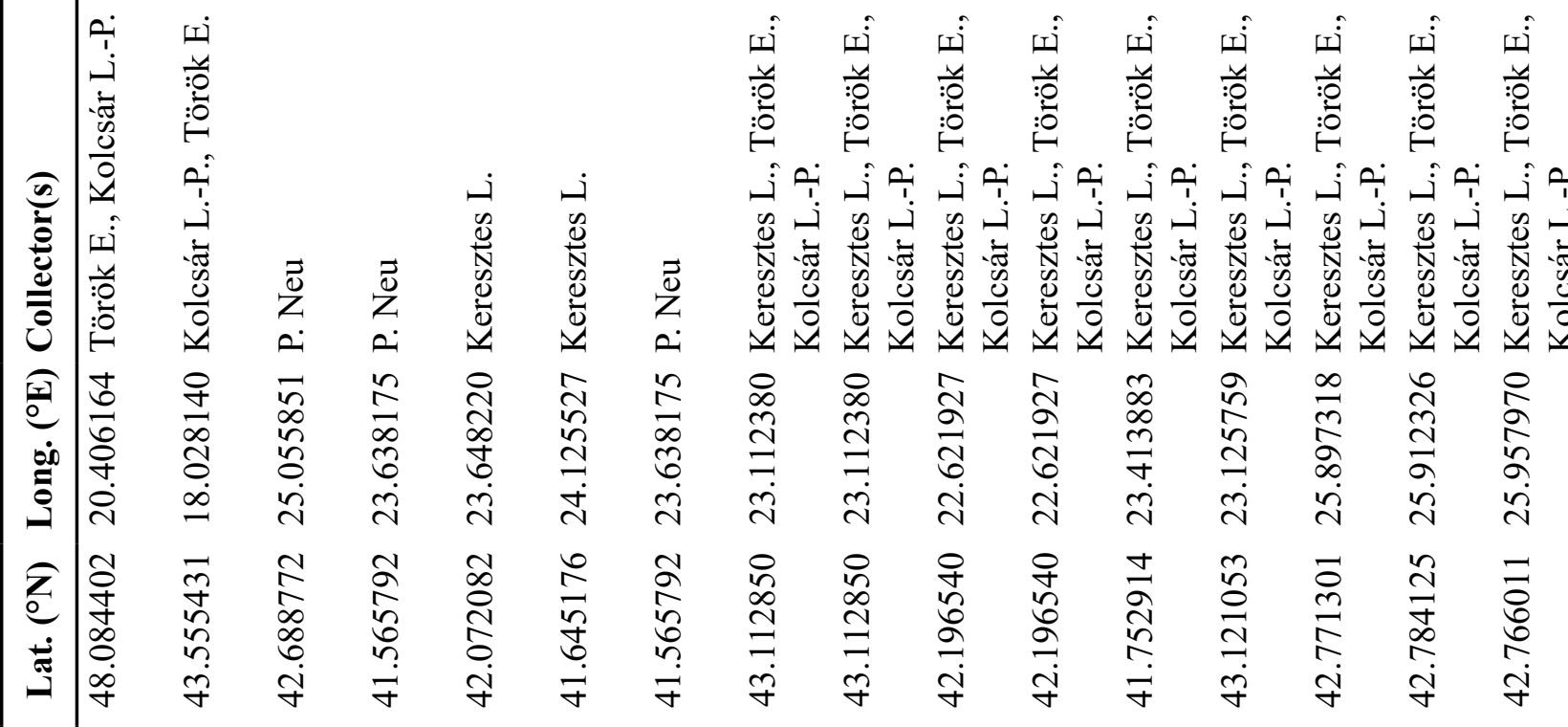

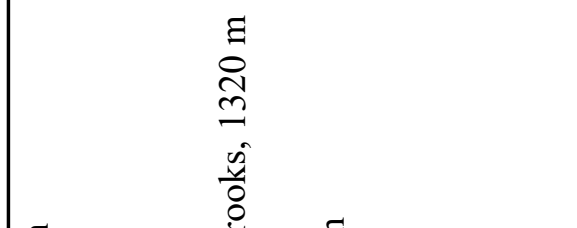

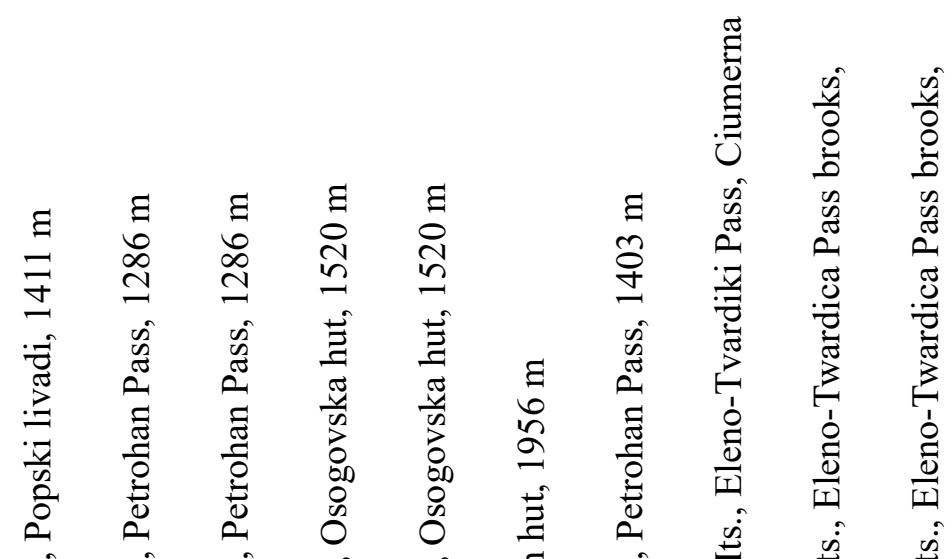

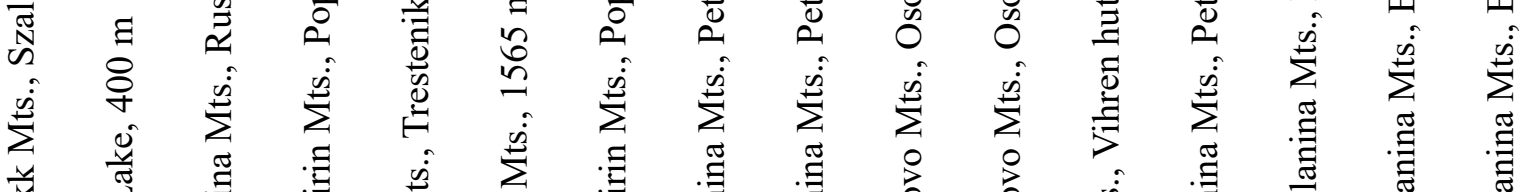

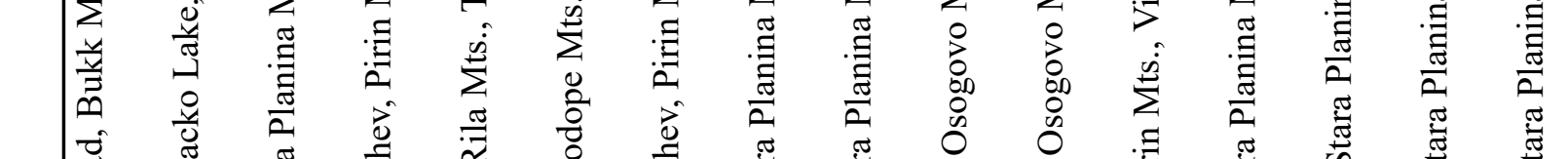

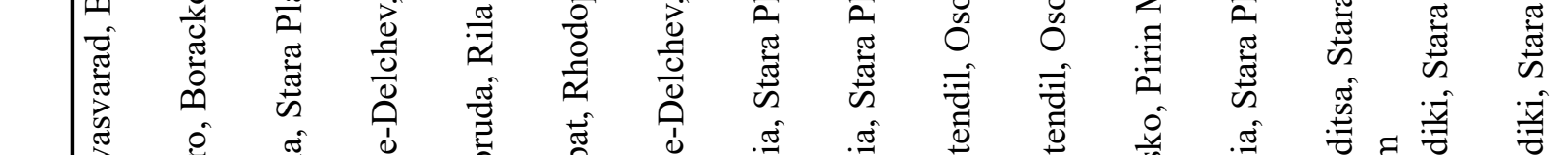

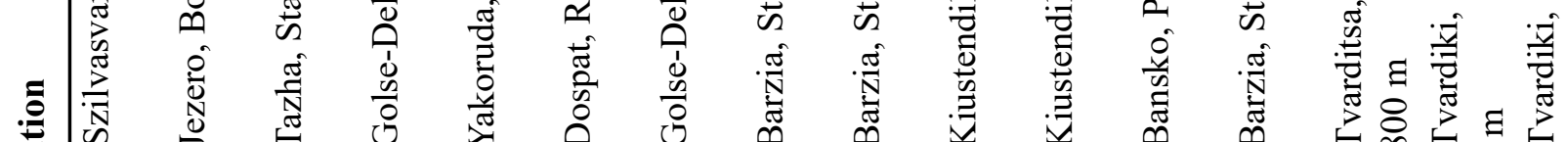
氙

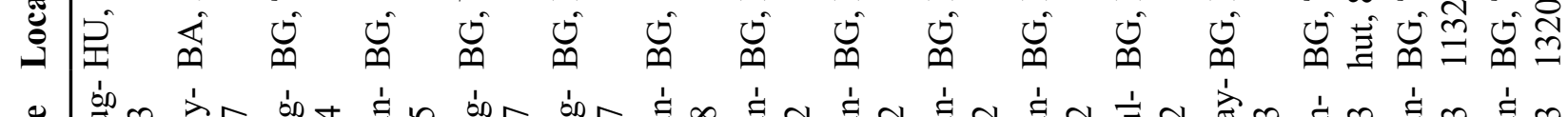
至

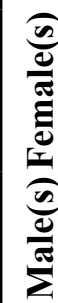

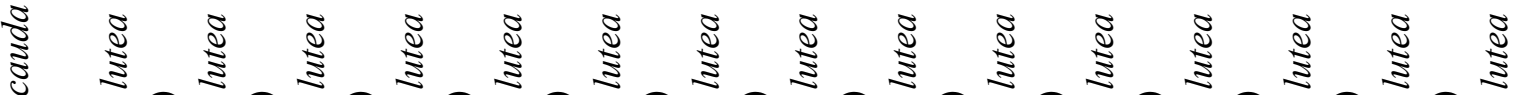

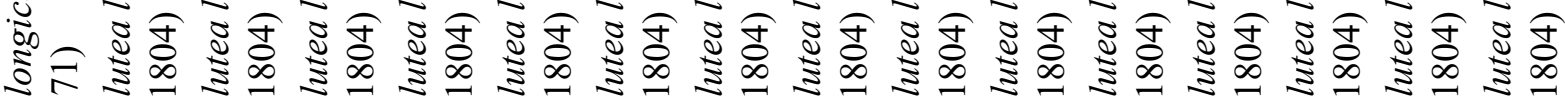

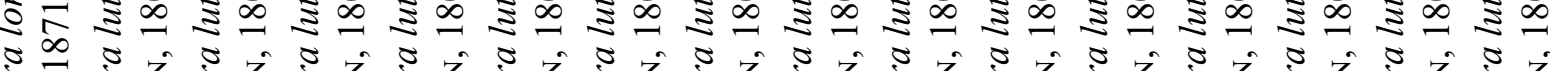

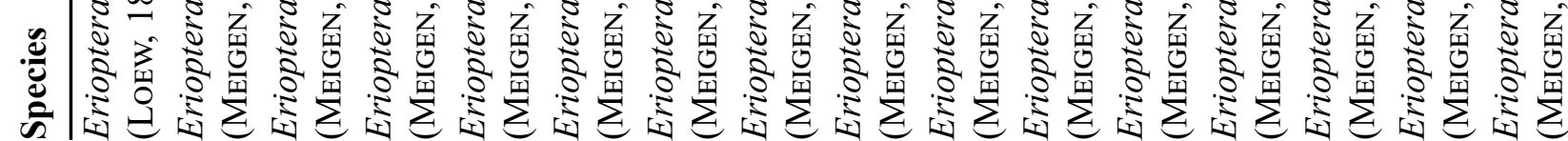




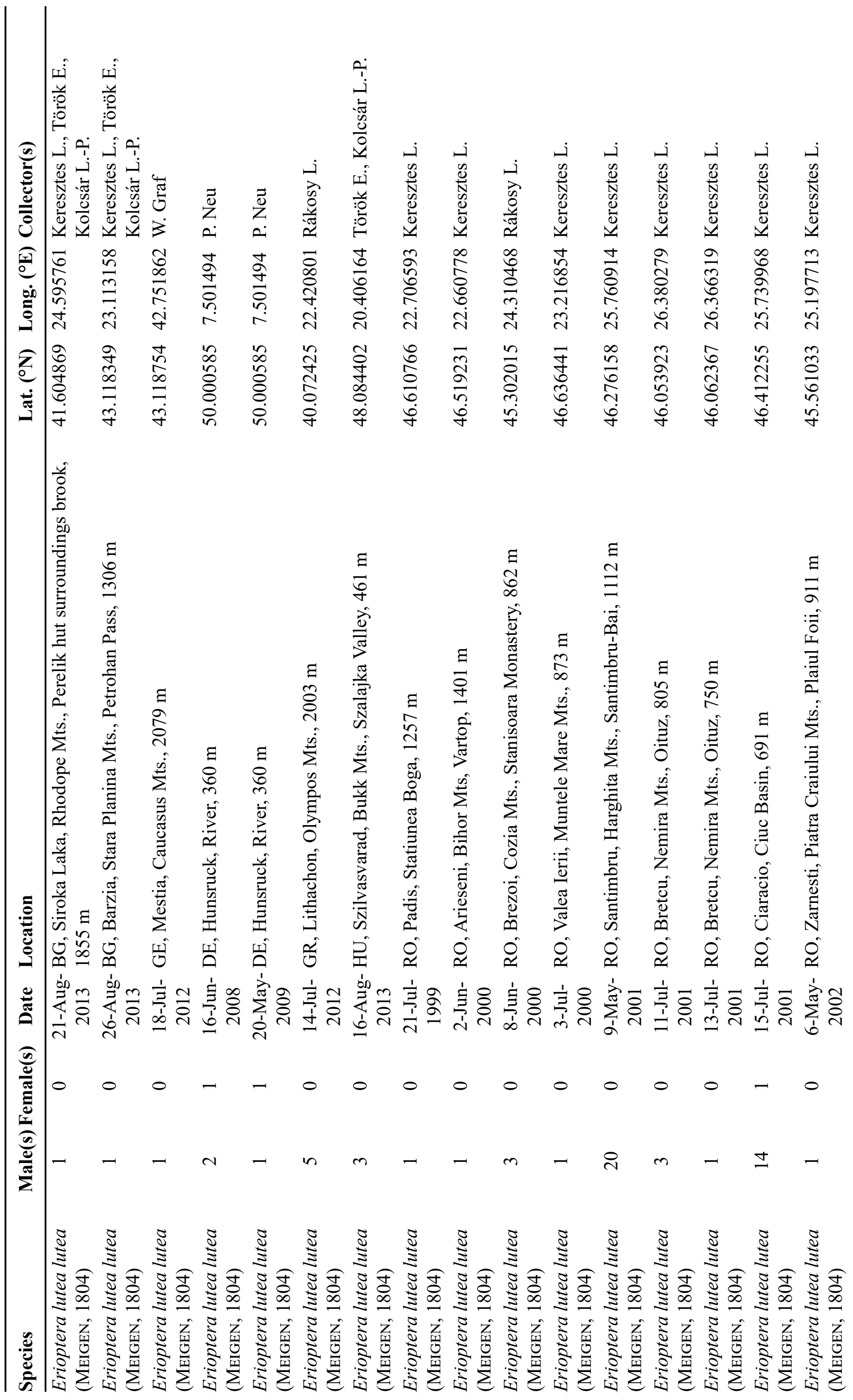




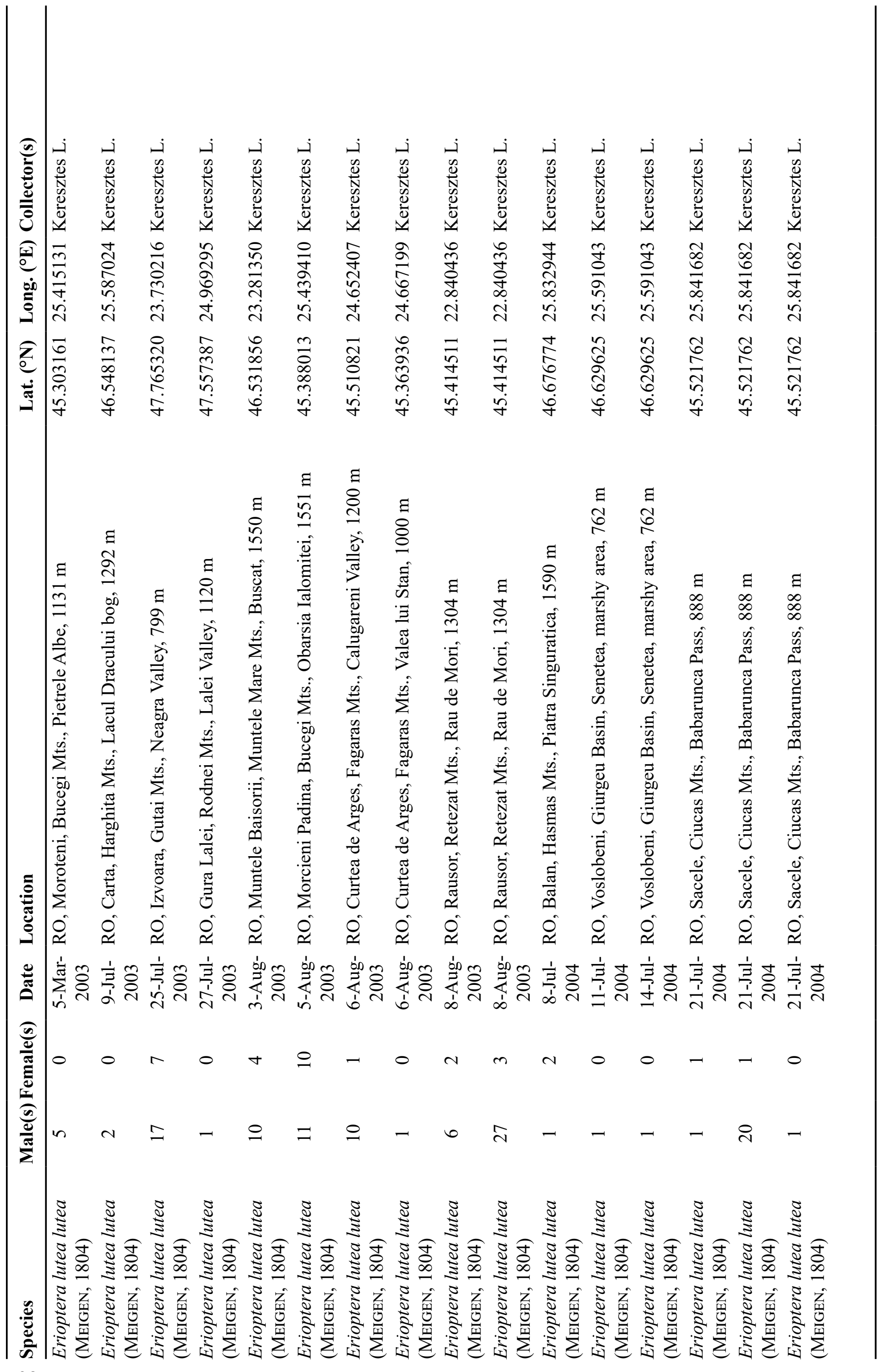




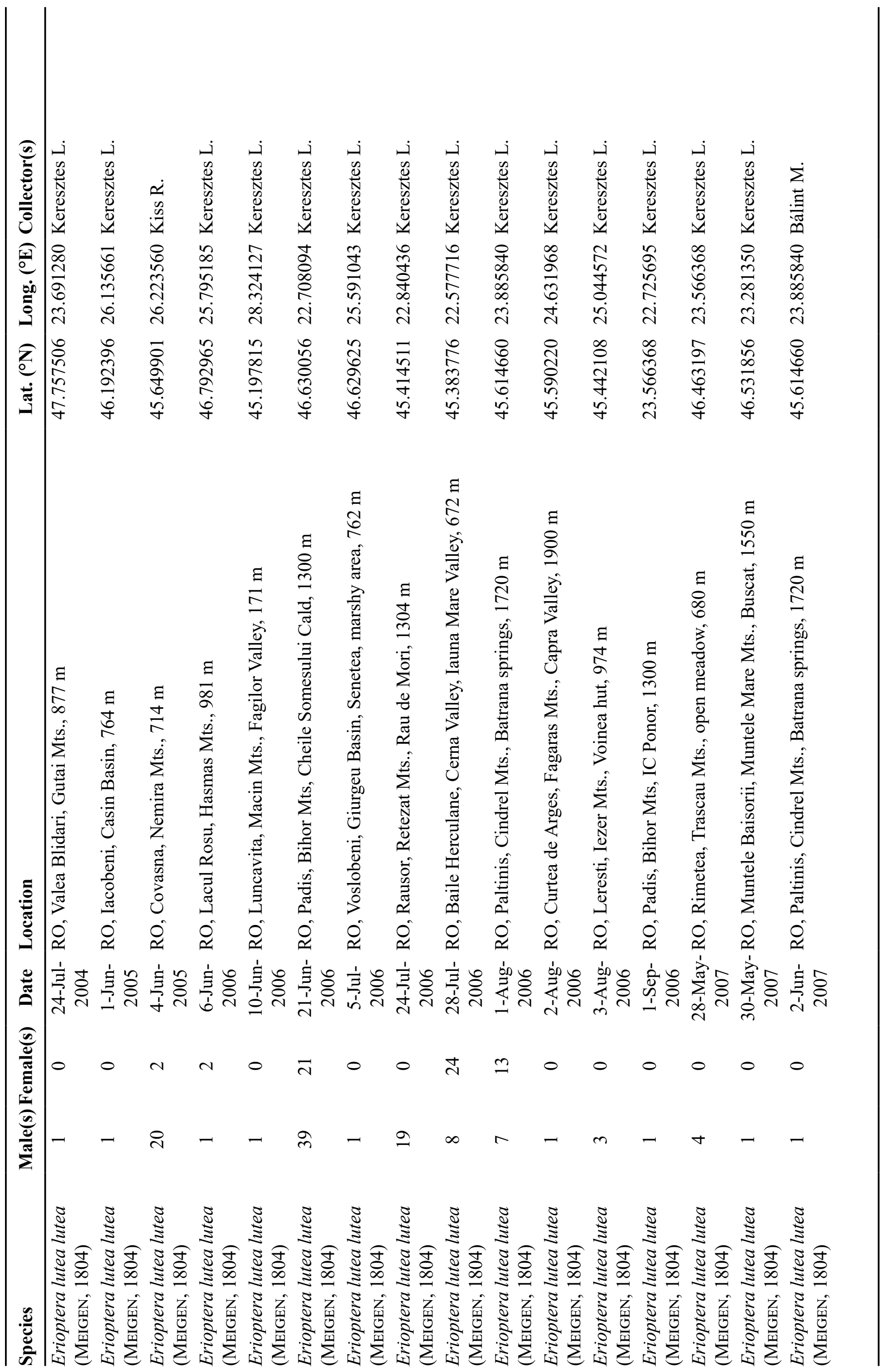




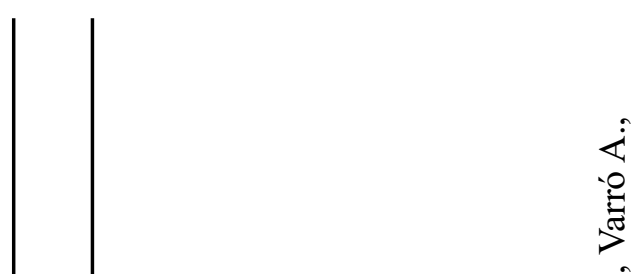

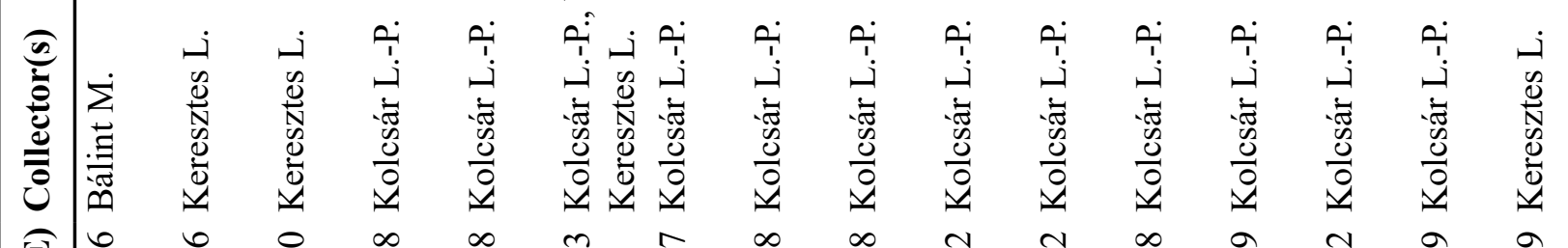

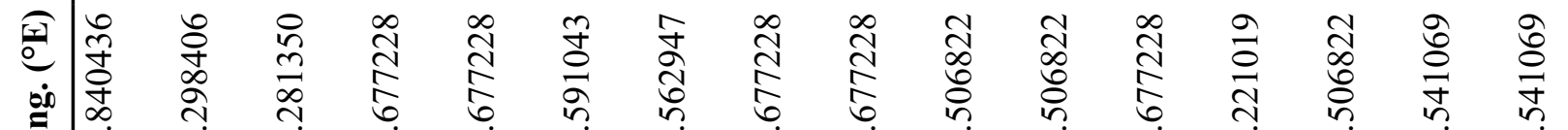

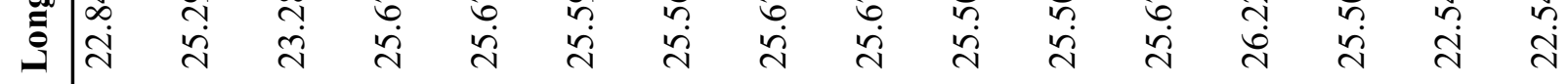

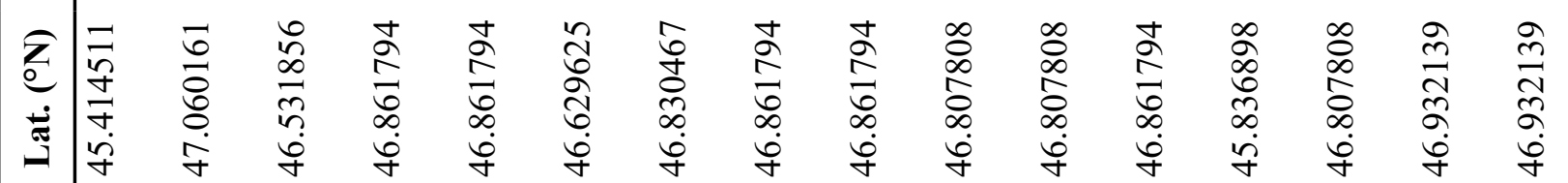

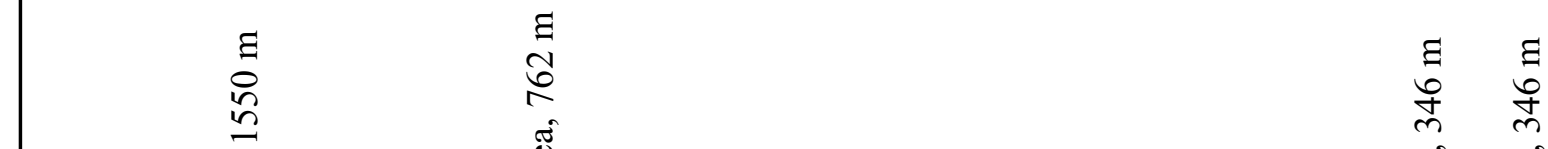

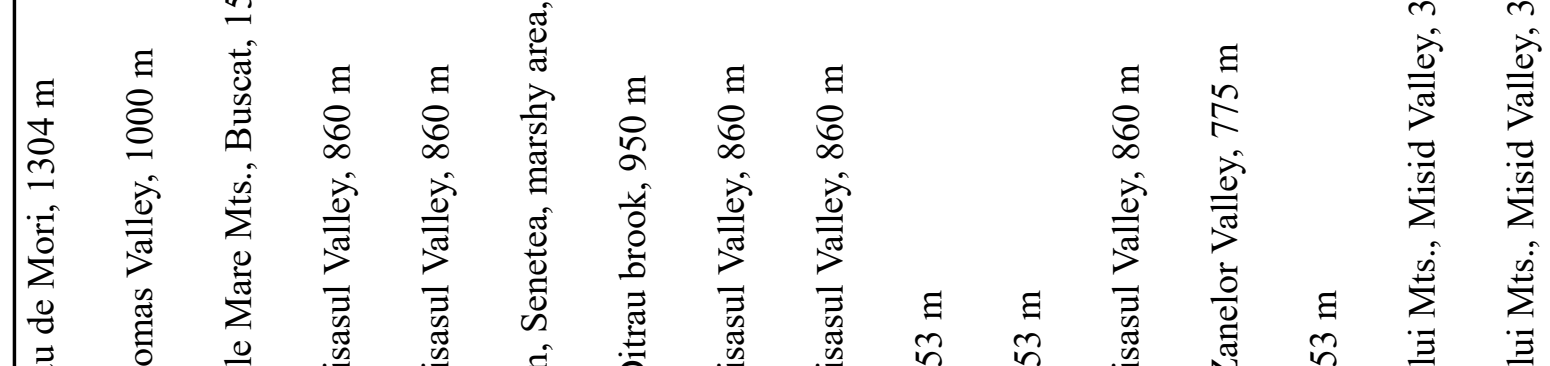

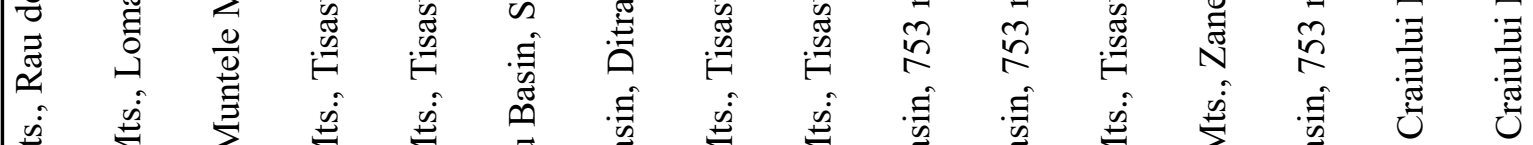

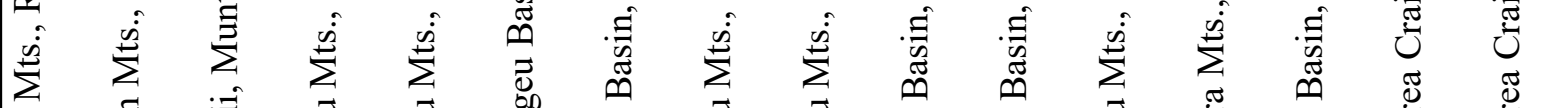

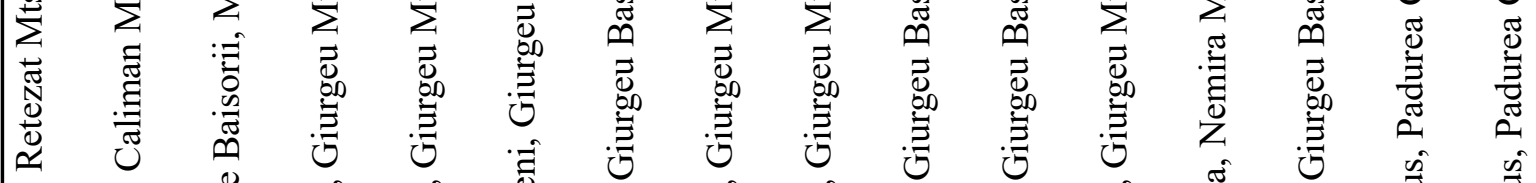

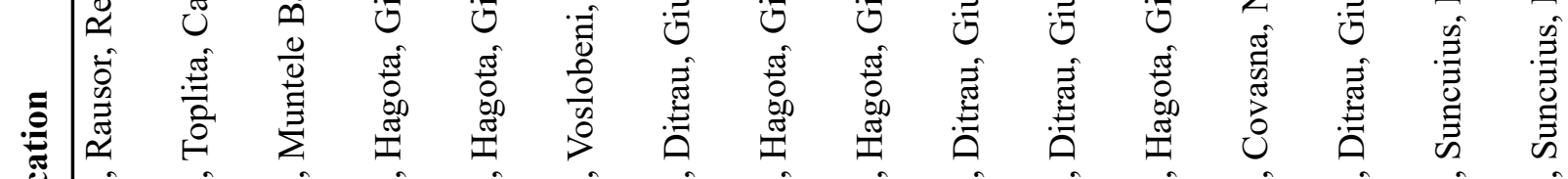

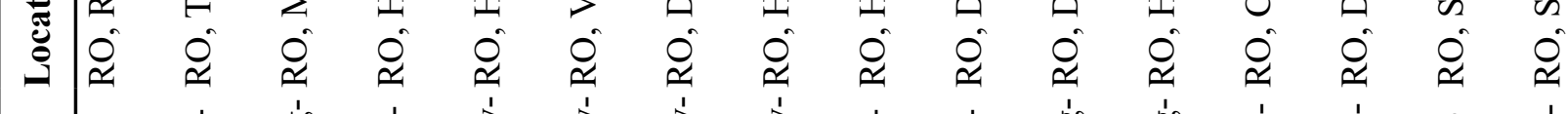

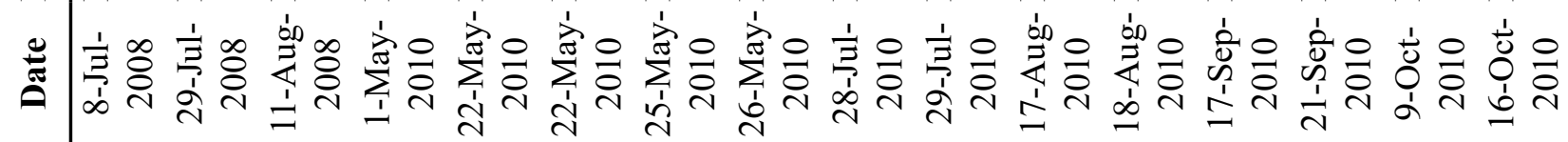

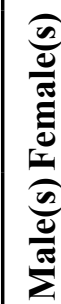

‡

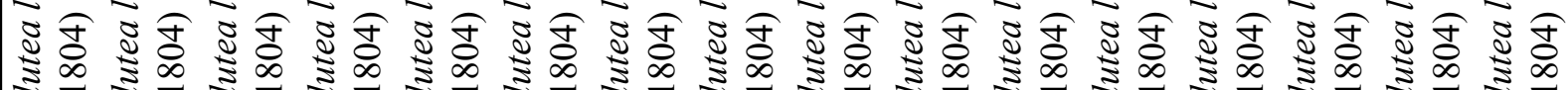

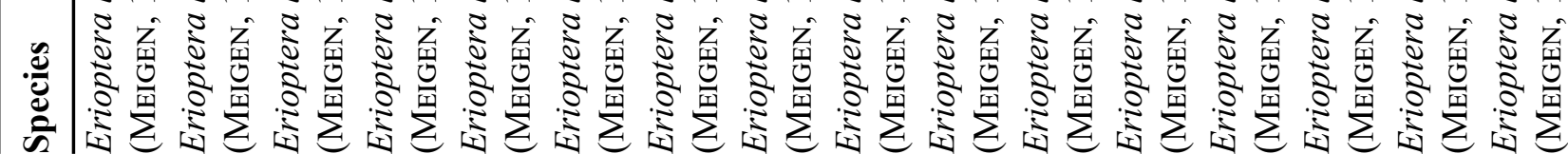




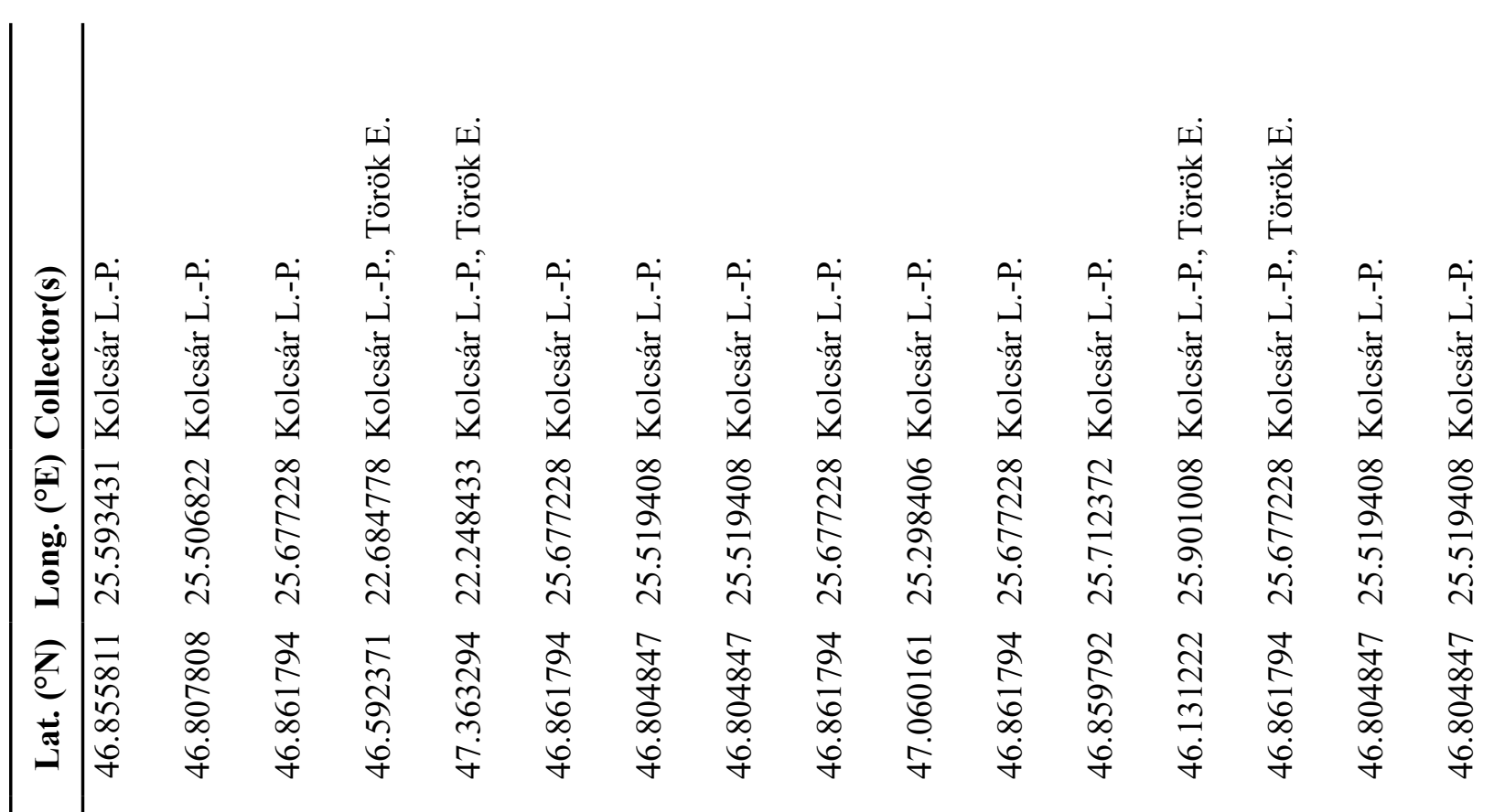

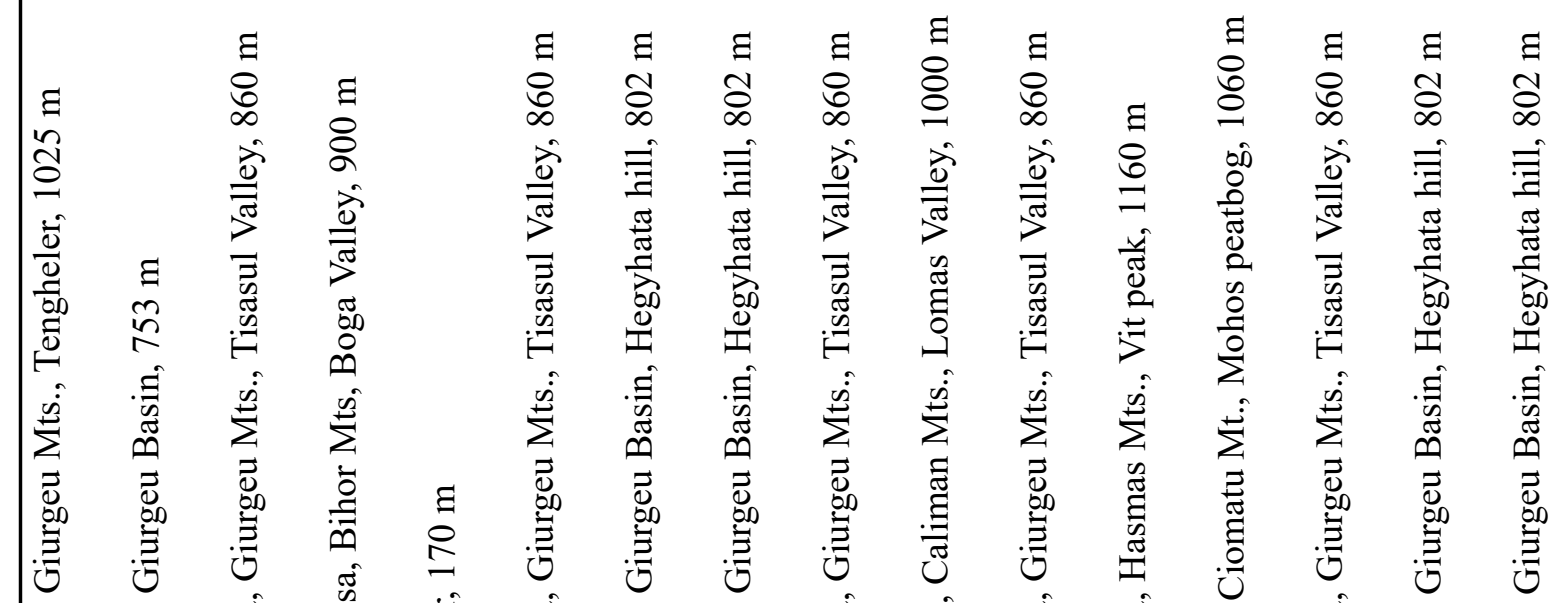

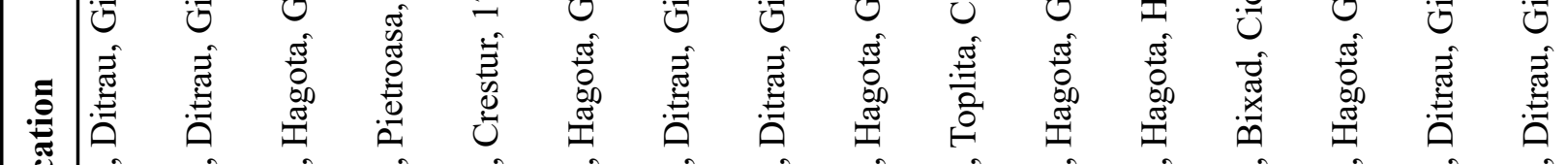

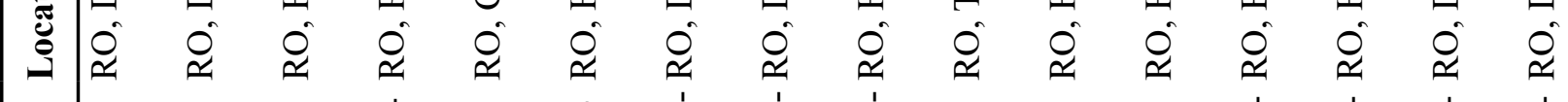

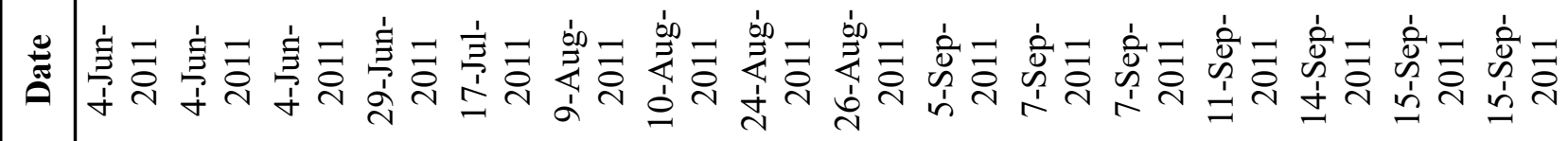

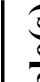

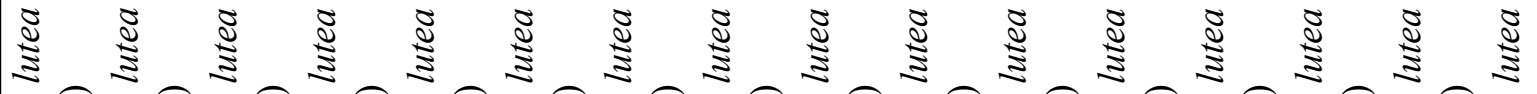
㺃

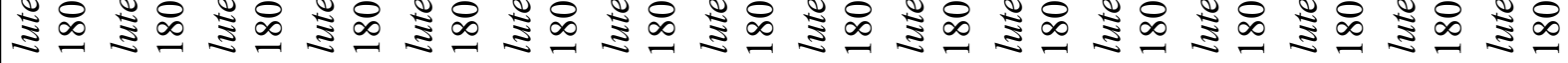

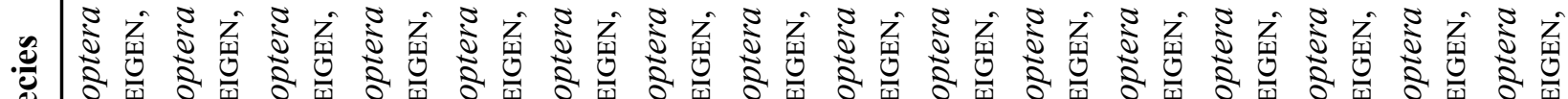

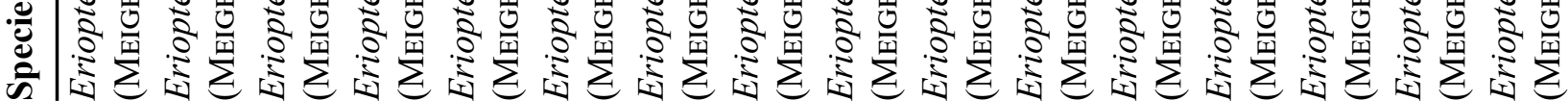




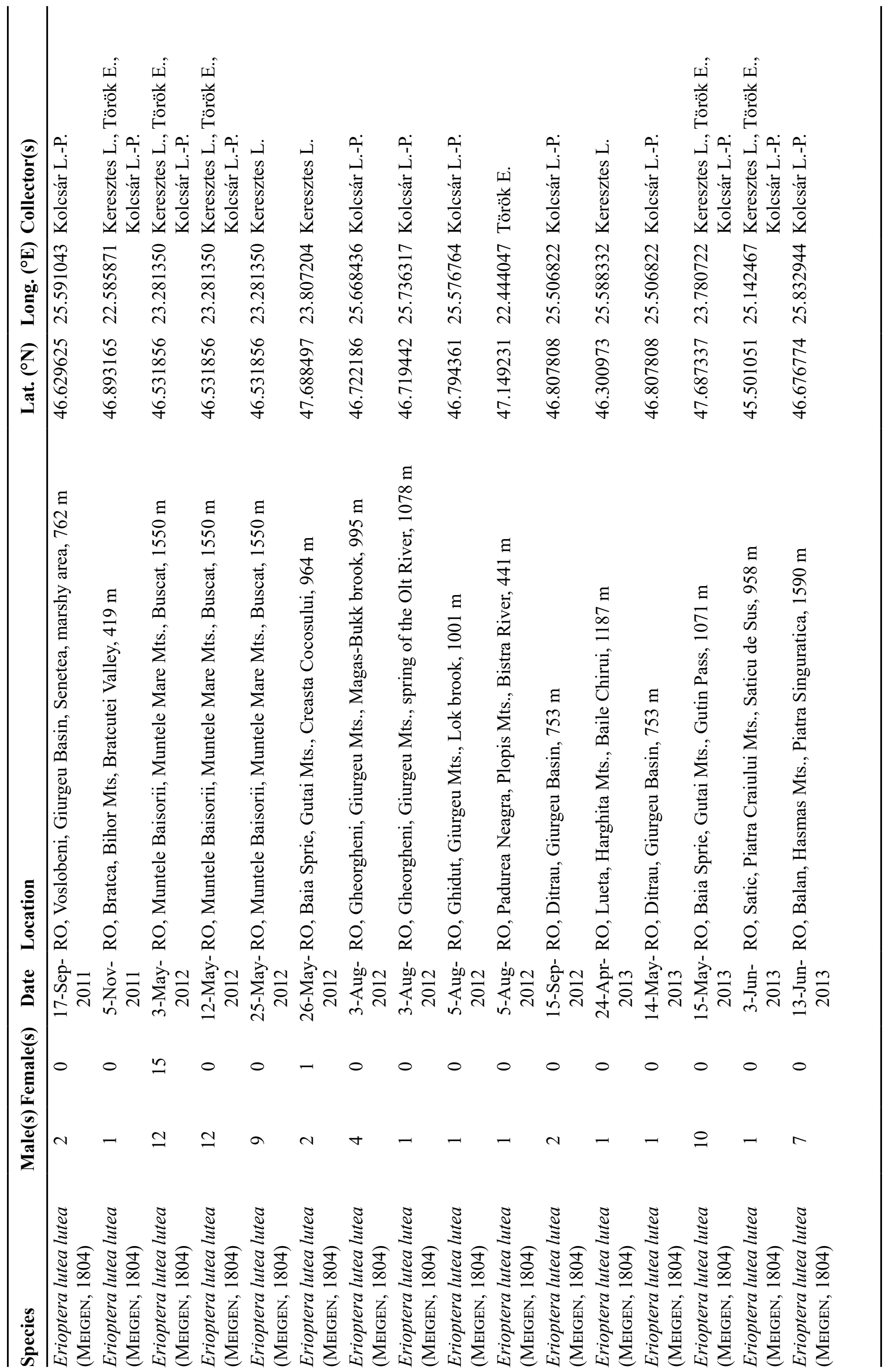




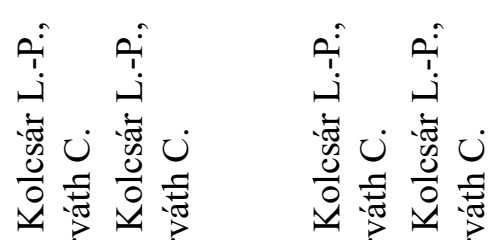

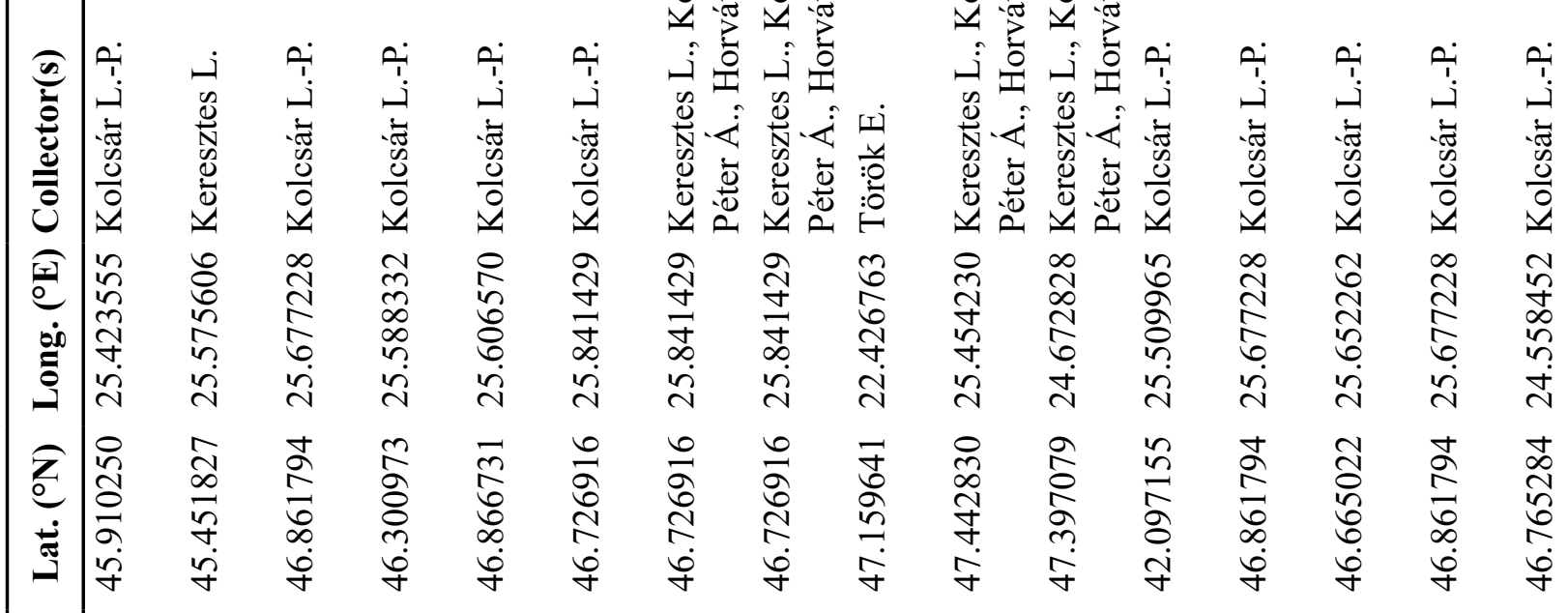

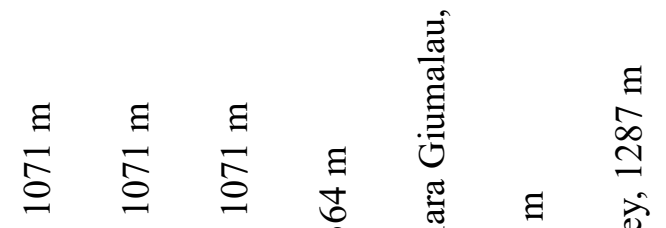

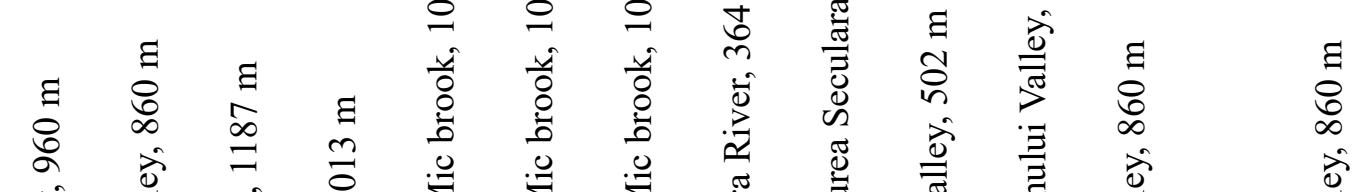

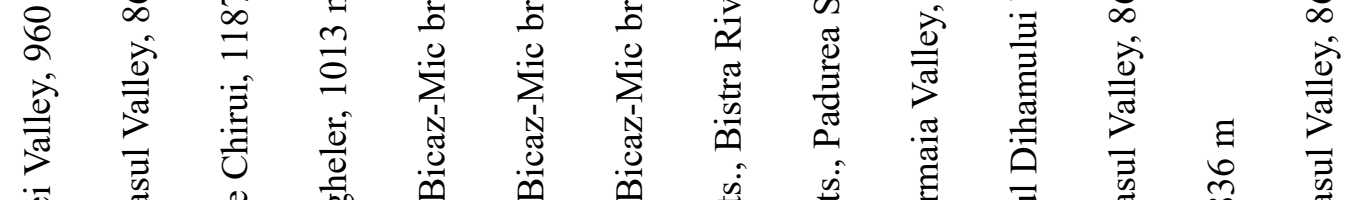

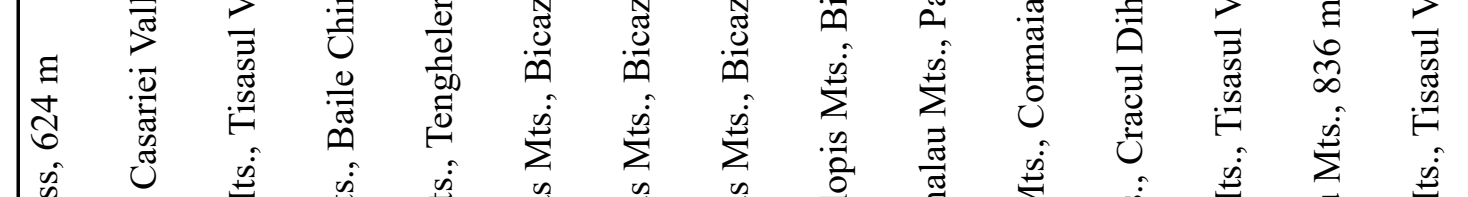

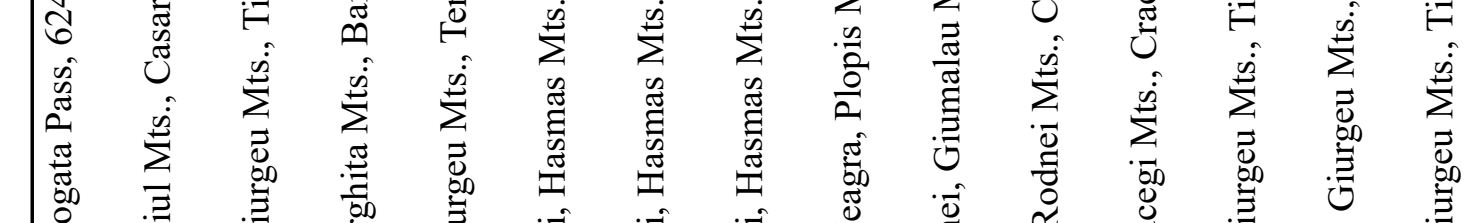

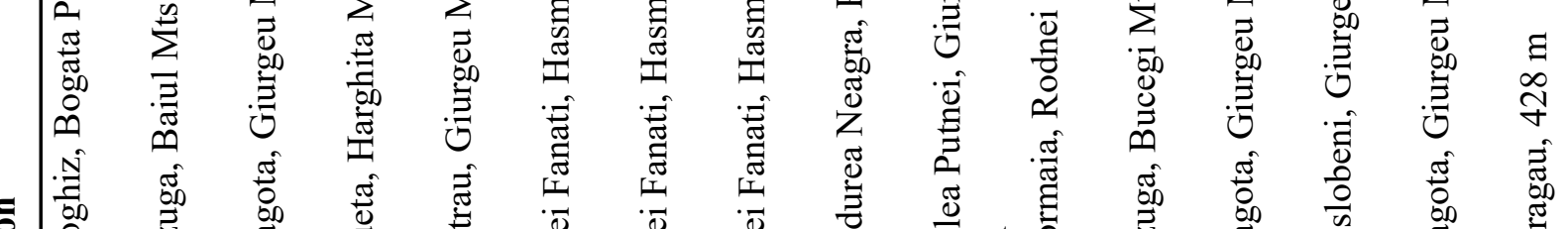

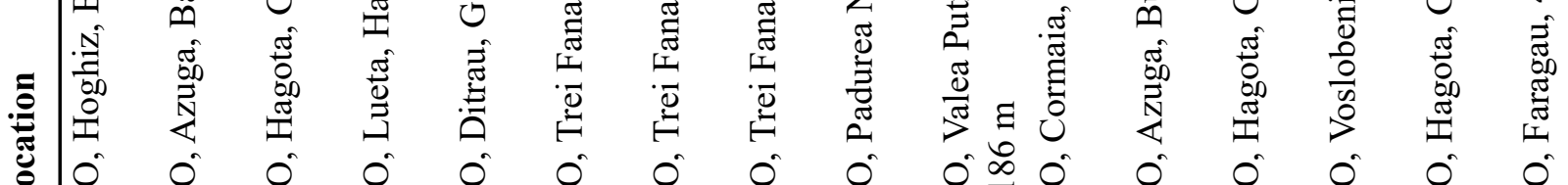

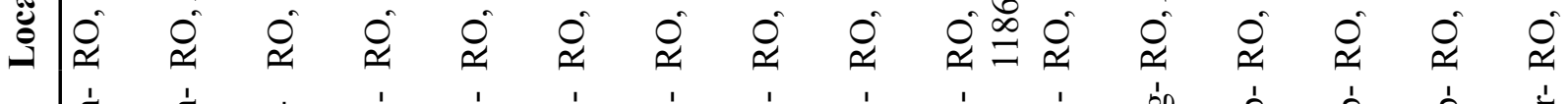

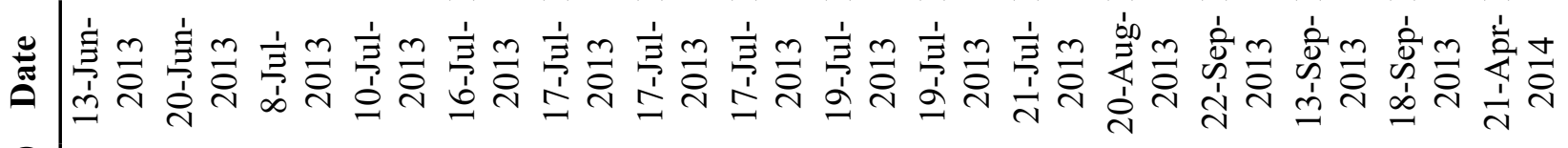

耪

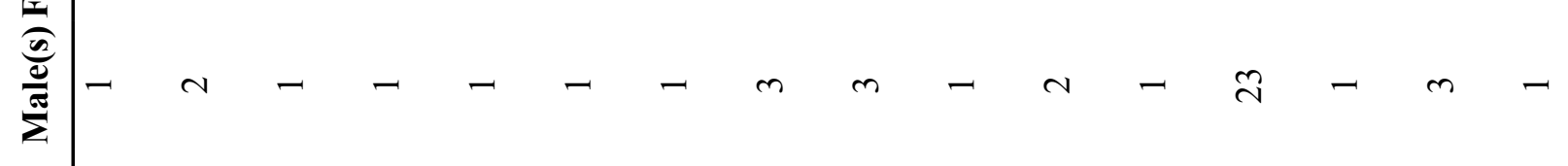

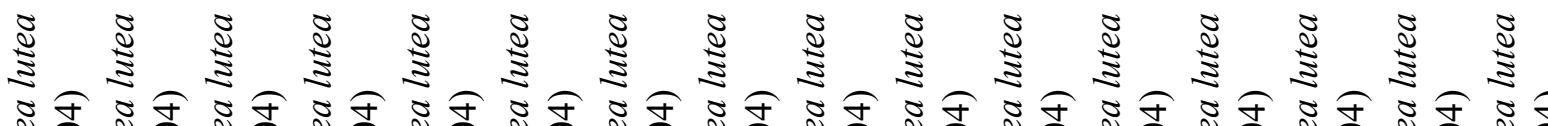

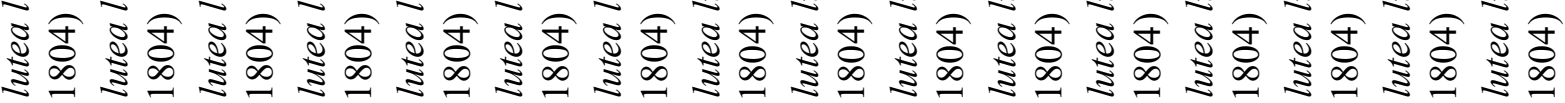

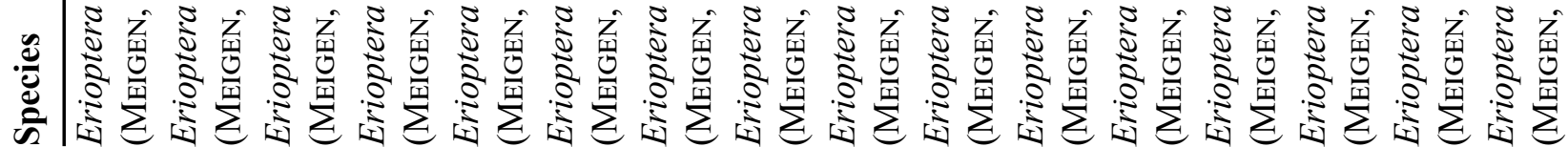




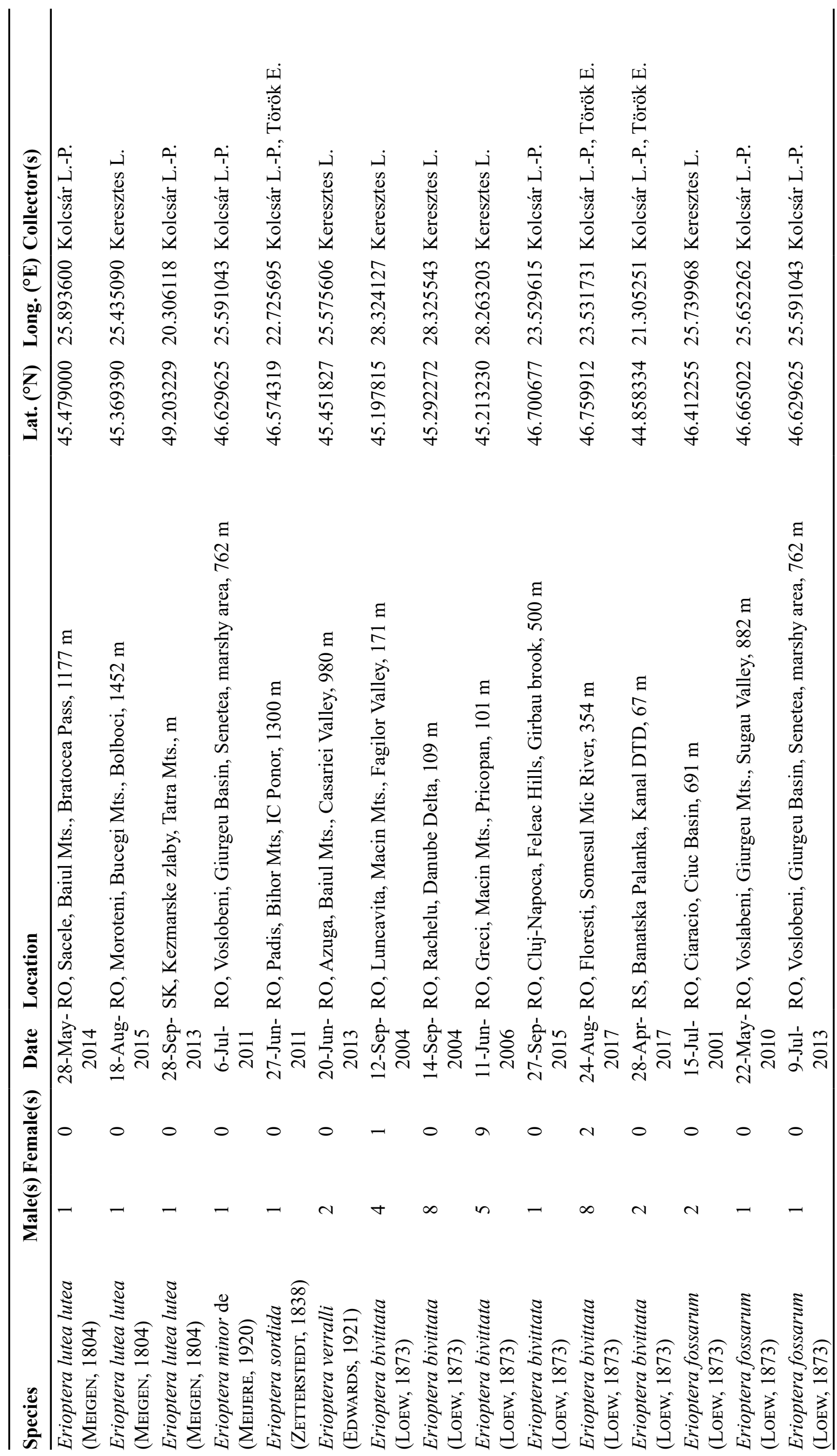

